\title{
European farmers' incentives to promote natural pest control service in arable fields
}

\section{Article}

\section{Accepted Version}

Creative Commons: Attribution-Noncommercial-No Derivative Works 4.0

Zhang, H., Potts, S. G., Breeze, T. and Bailey, A. (2018)

European farmers' incentives to promote natural pest control service in arable fields. Land Use Policy, 78. pp. 682-690. ISSN 0264-8377 doi:

https://doi.org/10.1016/j.landusepol.2018.07.017 Available at https://centaur.reading.ac.uk/79251/

It is advisable to refer to the publisher's version if you intend to cite from the work. See Guidance on citing.

To link to this article DOI: http://dx.doi.org/10.1016/j.landusepol.2018.07.017

Publisher: Elsevier

All outputs in CentAUR are protected by Intellectual Property Rights law, including copyright law. Copyright and IPR is retained by the creators or other copyright holders. Terms and conditions for use of this material are defined in the End User Agreement.

\section{www.reading.ac.uk/centaur}

\section{CentAUR}

Central Archive at the University of Reading 
Reading's research outputs online 


\section{European farmers' incentives to promote natural pest control service}

in arable fields

Han Zhang ${ }^{a, b, *}$; Simon G. Potts ${ }^{a} ;$ Tom Breeze $^{a}$; Alison Bailey

${ }^{\text {a }}$ Centre for Agri-Environmental Research, School of Agriculture, Policy and Development, University of Reading, Reading, Berkshire, RG6 6AR, UK

${ }^{\mathrm{b}}$ Crop Health, Faculty of Agricultural and Environmental Sciences, University of Rostock, Satower Straße 48, D-18051 Rostock, Germany

c Land Management and Systems, Faculty of Agribusiness and Commerce, Lincoln University, Lincoln 7647, Christchurch, New Zealand

* Corresponding author.

Email addresses: mzresearch99@gmail.com (H. Zhang), s.g.potts@reading.ac.uk (S.G. Potts), t.d.breeze@reading.ac.uk (T. Breeze), Alison.Bailey@lincoln.ac.nz (A. Bailey). 


\title{
European farmers' incentives to promote natural pest control service in arable fields
}

\begin{abstract}
Integrated pest management (IPM) is widely encouraged among the European Union (EU) member states. The successful adoption of IPM techniques requires strong farmer motivation and participation. However, few studies have explored EU farmers' incentives to promote natural enemies of crop pests in the fields, and none have addressed how this could be influenced by farmers' recognition of natural pest control service. Based on interviews among arable farmers involved in an EU funded agri-environmental project across seven member states, natural pest control was perceived to be a less important contributor to crop production than soil fertility and pollination. Preferences toward managing semi-natural habitats for natural enemies were also relatively low, while insecticides were commonly used among participants. Ordinal logistic regression indicates that farmers' decision to promote natural pest control was positively associated with the perceived importance of this ecosystem service for crop production. However, they expressed a relatively low confidence in the pest control efficacies of natural enemies compared with insecticides, especially under high pest damage levels. Farmers with greater income have more financial flexibility to adopt either pest control method. The environment surrounding a farm may also influence its owner's willingness to promote natural pest control.
\end{abstract}

\section{Key words}

Farmer attitudes; Pest control decision-making; Natural pest control service; Integrated pest management; Agri-environment schemes; European Union arable crops.

\section{Highlights}

- EU arable farmers' perceived value of natural pest control was relatively low

- Perceived value of natural pest control positively influences conservation actions

- A tendency to use insecticides under high pest infestation levels was revealed

- Richer farmers are more flexible to adopt related conservation techniques

- Environmental factors may influence farmers' decision to promote natural enemies 


\section{Introduction}

Since Stern et al. (1959) introduced the concept of integrated pest management (IPM) as 'applied pest control which combines and integrates biological and chemical control', this method has gradually gained recognition worldwide as a key element in more sustainable agricultural systems (Barzman et al., 2015; Birch et al., 2011). Although its definition varies among studies and organizations (Bajwa and Kogan, 2002), the key message is that IPM is a systemic approach which encourages the integration of multiple methods to control pests in a 'safe, cost-effective, and environmentally friendly manner' (Parsa et al., 2014).

IPM is also highly encouraged under the 'EU Pesticide Package', a suite of European Union legislation (EU 2009a-d). Member states are required to develop National Action Plans to support their professional pesticide users in following the eight general principles of IPM (EU 2009b-c). The first principle (prevention and suppression) stresses the importance of protecting and enhancing natural pest control in the fields (EU 2009b).

Indeed, natural pest control is an important ecosystem service in the agricultural sector, which could help suppress pest damage and, by reducing the unnecessary insecticide inputs, reduce incidence of pest resistance (Power, 2010). Its value towards crop protection has been characterised through field experiments (Safarzoda et al., 2014; Thies et al., 2011), ecological modelling (Jonsson et al., 2014) and economic evaluation (Naranjo et al., 2015; Zhang et al., 2018). In this study, 'pests' referred to are animal pests, and natural enemies as the related species that target these pests.

Natural pest control is negatively influenced by the on-going agricultural intensification (Crowder and Jabbour, 2014), either through a subsequent increase in pesticides (especially insecticides) (Geiger et al., 2010), or the loss of (semi-) natural habitats from cropland expansion (Zhao et al., 2015). To enhance the contribution of this ecosystem service to crop protection, the EU Framework Directive 2009/128/EC has provided guidelines on using insecticides strategically: e.g., monitoring pest populations in the fields and using action thresholds to determine applications (Hallett et al., 2014). Also, as an important tool to conserve biodiversity, the agri-environment schemes (AES) have provided EU farmers options to establish/manage semi-natural habitats on their farmland (Batáry et al., 2015). This has shown positive effects on promoting natural pest control (Holland et al., 2016): e.g., hedgerows (Stutz and Entling, 2011), beetle banks (Collins et al., 2002), and cover crops (Aguilar-Fenollosa et al., 2011). 
Nonetheless, the successful adoption of these techniques requires strong farmer participation, which is also an important element in the IPM regime (Junge et al., 2009; Lefebvre et al., 2015). However, knowledge gaps remain in understanding EU farmers' incentives to apply related techniques to promote natural pest control in the fields (Lefebvre et al., 2015). Although numerous studies have shown natural pest control is valuable for sustainable agriculture (Letourneau et al., 2009), few have examined whether it is valuable from a farmer's perspective (Segura et al., 2004). To our knowledge, no studies have analysed the influence of farmers' perceptions of natural pest control on their decision-making in promoting this ecosystem service.

Based on an interview survey with arable farmers in seven EU countries, this study assesses the potential factors influencing farmers' decisions on whether to promote natural pest control in their fields. In particular, it focuses on how farmers' perceptions of natural pest control service influence their conservation actions. In parallel, the potential factors influencing farmers' decisions on using insecticides are analysed.

\section{Methods}

\subsection{Interview area and process}

To gather relevant information on farmer perception and management, 85 farmers participating in the EU funded LIBERATION (Linking farmland biodiversity to ecosystem services for effective ecofunctional intensification, www.fp7liberation.eu) project across Germany (11 participants), Hungary (18), Italy (13), Netherlands (20), Poland (10), Sweden (5), and the UK (8) were face-to-face interviewed. Farmers were recruited from the farmer networks associated with the research institutes involved in the LIBERATION project in each country. The interviewees represented the farm businesses who provided field sites to support experimental work within this project, which aims to quantify the contribution of multiple ecosystem services (e.g., natural pest control) towards crop production, and to analyse the effectiveness of environmental management practices (e.g., hedgerows) for promoting these ecosystem services. The participants were a combination of farm owners $(82 \%)$, managers $(27 \%)$ and tenants $(18 \%)$. They were primarily arable farmers, and grew mostly wheat (99\%), maize (45\%), sugar beet (42\%), and oilseed rape (35\%; Appendix A). The interviews were conducted in the autumn and winter of 2014, after field sites were selected and initial experimental works undertaken. 


\subsection{Interview contents}

The questionnaire (Appendix B) elicited information on farmers' perspectives on three ecosystem services (natural pest control, pollination, and soil fertility) and disservices (pest, weed, and disease damage). For the scope of this paper, we focus on the following areas: (i) background information about the farms, (ii) preferences towards on-farm environmental management practices, (iii) perceptions of natural pest control service and pest damage.

The information about the farms included agricultural area (ha), average number of crops used in a rotation, average annual farm income $(€$, following a seven point scale from $1=$ loss through to $7=>$ $€ 100,000$, and included a 'Prefer not to say' option) for the last two financial years, years of farming, whether a farm is in a designated area of environmental interest $\left(0=\right.$ ' $\mathrm{No}^{\prime}, 1=$ 'Yes'; the following questions with the same structure also used this code), and whether a farm is involved in an agrienvironment scheme (AES).

The farmers were then asked to indicate their attitudes towards 17 environmental management practices (Appendix C), covering those being implemented across the study sites and additional environmental options not implemented. This followed a three point scale: 1 = 'Dislike' to $3=$ 'Like' (and also included an 'Unfamiliar' option).

Finally, the perceived importance of natural enemies and pest damage for crop production were captured by a four point scale, from 1 = 'Relatively unimportant' to $4=$ 'Very important'. The number of perceived important natural enemy and pest species on-farm were also recorded. In terms of pest management, the number of methods used to promote natural pest control (Appendix E) and whether the farmers use chemicals to manage pests were recorded.

\subsection{Statistical analyses}

All analyses were done using R 3.2.5 (R Core Team, 2016), with significance levels set as 0.05. Mean values and standard deviations were used to summarize the data in the tables. If a data distribution is skewed, median values were also used to present the results to take into account outliers.

Information about farms and the perceptions of natural pest control service and pest damage were compared among seven countries using a Kruskal-Wallis one-way analysis of variance by ranks $(R$ Core Team, 2016) and related post-hoc tests (Pohlert, 2014), to account for ordinal data characteristics and difference in data distribution. 
For the environmental management practices provided in the survey, those that potentially provide semi-natural habitats with forage, shelter and reproductive opportunities for natural enemies were selected and grouped by the habitat management types reviewed from Holland et al. (2016) (Appendices C\&D). For multiple management practices in the same group, the average preference score was calculated to represent a respondent's opinion for this habitat type. The perceived preference for each habitat management was compared among seven countries using the same method as for the information about farms and the farmers' perceptions outlined above.

To compare the perceived preferences among habitat management types, the Skillings-Mack (Srisuradetchai, 2015) and related post-hoc tests (Pohlert, 2014) were conducted. Following the same method, the perceived importance of natural pest control was compared with the other ecosystem services and disservices in this study.

Then, ordinal logistic regressions were used to analyse the potential factors that influenced the farmers' decision to promote natural pest control (Christensen, 2015a). The response variable was the number of methods mentioned by each participant to promote natural pest control, and the potential explanatory variables were the information about the farms (Table 1) and farmers' perceptions of natural pest control service and pest damage (Table 3). Farmers' preferences toward habitat management types (Table 2) were excluded in the model, because semi-natural habitats could potentially promote multiple ecosystem services, and it is unclear whether a respondent's opinion on a habitat type is primarily related to promoting natural pest control.

Based on the Kendall's Tau b association and related post-hoc tests (McLeod, 2011; R Core Team, 2016), the initial model included all variables from Tables $1 \& 3$ that have statistically significant associations with the response variable (i.e., importance of natural pest control, farm income, and whether a farm was located in a designated area of environmental interest; Appendix F). Because country differences were acknowledged for several variables (Tables 1\&3), the variable 'Country' was firstly included as a random effect in the initial model, but was then taken out due to its nonsignificance by a likelihood ratio test (Christensen, 2015b).

Then, Wald statistics (the ratio of the coefficient to its standard error) were used to test whether the coefficient of each variable in the initial model was significantly different from zero, based on the normal distribution. If so, that variable was removed. Then, the rest of the variables from Tables $1 \& 3$ were added to the model one at a time. At each step, each variable that was not in the model was tested for inclusion in the model, and the most significant one was added to the model. This process continued until none of the remaining variables were significant when added to the model. Model convergence and fitness were assessed (Christensen, 2015c), and McFadden's Pseudo R-Square was 
then estimated (McFadden, 1973). Potential factors that influenced a farmer's decision to use insecticides for crop protection were modelled following the same procedure.

\section{Results}

\subsection{Information about farms}

Based on the $85 \mathrm{EU}$ farmers involved in the LIBERATION project, there were significant differences between countries in terms of farm size, with the UK participants having the greatest agricultural area (average 446 ha) and Italian the smallest (average 17 ha) (Table 1). This was also reflected in the farm income, with UK reaching the highest annual income level (average $>=€ 100,000$ ), and Poland and Italy the lowest $(€ 1-20,000)$. Differences also existed in terms of the agri-environment scheme (AES) participation, with UK having the most participants involved (88\%), while no participants in Poland were involved. Across all countries there were similarities in the number of crops within a rotation (average three) and the number of years in farming (average 25 years).

\begin{tabular}{|c|c|c|c|c|c|c|c|}
\hline & Germany & Hungary & Italy & Netherlands & Poland & Sweden & UK \\
\hline $\begin{array}{l}\text { Agriculture area } \\
\text { (hectare) }\end{array}$ & $\begin{array}{l}94.9(11 ; 70.5) \\
\text { ac }\end{array}$ & $\begin{array}{l}114.3(18 ; 73.4) \\
a\end{array}$ & $\begin{array}{l}17.1(13 ; 28.6) \\
b\end{array}$ & $122.6(20 ; 176.7)$ ac & $\begin{array}{l}43.7(10 ; 52.8) \\
\text { bc }\end{array}$ & $\begin{array}{l}330.0(5 ; 460.4) \\
\text { ad }\end{array}$ & $\begin{array}{l}446.3(8 ; 178.8) \\
d\end{array}$ \\
\hline $\begin{array}{l}\text { \# of Crops for a } \\
\text { rotation }\end{array}$ & $3.3(11 ; 0.4)$ ab & $2.9(18 ; 0.8) b$ & $3.3(13 ; 0.9) a b$ & $3.9(20 ; 0.7)$ a & $3.5(9 ; 0.8) a b$ & $3.4(5 ; 0.6)$ ab & $3.0(8 ; 0.5) a b$ \\
\hline Farm income & $4.8(8 ; 1.6) \mathrm{ac}$ & $4.3(15 ; 2.2) \mathrm{ad}$ & $1.9(13 ; 0.6) b$ & $5.3(12 ; 1.6) \mathrm{ac}$ & $2.4(7 ; 0.5) b d$ & $4.4(5 ; 1.5)$ acd & $6.6(8 ; 1.1) c$ \\
\hline $\begin{array}{l}\text { Years of } \\
\text { farming } \\
\text { In a designated }\end{array}$ & $25.3(10 ; 15.5)$ & $25.3(18 ; 10.1)$ & $29.3(13 ; 9.2)$ & $26.5(20 ; 7.1)$ & $21.8(10 ; 7.8)$ & $26.2(5 ; 14.8)$ & $26.5(8 ; 18.1)$ \\
\hline $\begin{array}{l}\text { area of } \\
\text { environmental } \\
\text { interests? } \\
\text { In an agri- }\end{array}$ & $0.09(11 ; 0.3)$ ac & $0.8(18 ; 0.4) b$ & $0.08(13 ; 0.3) \mathrm{cd}$ & $0.0(20 ; 0) \mathrm{ad}$ & $0.3(9 ; 0.5) \mathrm{bcd}$ & $0.2(5 ; 0.5)$ ac & $0.5(8 ; 0.5) b c$ \\
\hline $\begin{array}{l}\text { environment } \\
\text { scheme? }\end{array}$ & $0.1(7 ; 0.4) a b$ & $0.6(18 ; 0.5) a b$ & $0.5(10 ; 0.5) a b$ & $0.5(17 ; 0.5) a b$ & $0(7 ; 0) a$ & $0.3(4 ; 0.5) a b$ & $0.9(8 ; 0.4) b$ \\
\hline
\end{tabular}

Table 1. Pairwise comparisons among countries of the general information about the farms: mean (\# of respondents; standard deviations).

Note: '\#' denotes 'number'; farm income: the average annual farm income for the last two financial years, preceding the date of the survey ( $€$, following a seven point scale: $1=$ loss, $2=1-20,000,3=20,001-40,000, \ldots$, $6=80,000-100,000,7=>100,000)$; questions follow the codes of: 0 = 'No', 1 = 'Yes'; different letters within a row indicate significant differences at $p<0.05$. 


\subsection{Preferences toward habitat management types}

Overall, the EU farmer participants had similar preferences towards various habitat management types suggested by the AES (average opinion 'Indifferent') (Fig 1). Preferences for the herbaceous ungrazed habitat, low-input cereal headlands, and undersowing/ cover crops were similar across countries ('Indifferent'). Italian and UK respondents expressed relatively high preferences for linear woody, grassy linear, and other AES habitats. Except for other AES habitats, Hungarian respondents expressed relatively low preference towards all options (Table 2).

\begin{tabular}{|c|c|c|c|c|c|c|c|}
\hline & Germany & Hungary & Italy & Netherlands & Poland & Sweden & UK \\
\hline Linear woody & $\begin{array}{l}2.6(9 ; 0 ; 0.9) \\
\mathrm{ab}\end{array}$ & $1.5(18 ; 0 ; 0.7) \mathrm{c}$ & $2.8(13 ; 2 ; 0.4) a$ & NA & $1.6(8 ; 1 ; 1.0) b c$ & $\begin{array}{l}2.4(5 ; 0 ; 0.9) \\
\text { ac }\end{array}$ & $\begin{array}{l}2.9(8 ; 0 ; 0.4) \\
a\end{array}$ \\
\hline Grassy linear & $\begin{array}{l}2.0(8 ; 0 ; 0.6) \\
a b\end{array}$ & $1.8(18 ; 0 ; 0.7) \mathrm{a}$ & $2.6(13 ; 1 ; 0.4) b$ & $\begin{array}{l}2.5(10 ; 1 ; 0.8) \\
\mathrm{b}\end{array}$ & $1.7(9 ; 2 ; 0.8) a b$ & $\begin{array}{l}2.8(3 ; 0 ; 0.4) \\
a b\end{array}$ & $\begin{array}{l}2.4(8 ; 0 ; 0.5) \\
a b\end{array}$ \\
\hline $\begin{array}{l}\text { Herbaceous } \\
\text { ungrazed } \\
\text { Low-input }\end{array}$ & $2.3(9 ; 0 ; 1.0)$ & $1.8(18 ; 0 ; 0.7)$ & $1.4(13 ; 1 ; 0.7)$ & $1.9(20 ; 3 ; 0.9)$ & $1.4(10 ; 3 ; 0.8)$ & NA & $2.3(8 ; 0 ; 1.0)$ \\
\hline $\begin{array}{l}\text { cereal } \\
\text { headlands }\end{array}$ & $2.3(8 ; 0 ; 0.9)$ & $1.7(18 ; 1 ; 0.7)$ & $2.6(13 ; 4 ; 0.7)$ & NA & $2.0(9 ; 2 ; 1.0)$ & NA & $2.0(7 ; 0 ; 1.0)$ \\
\hline $\begin{array}{l}\text { Undersowing } \\
\text { and cover } \\
\text { crops }\end{array}$ & $2.1(8 ; 1 ; 0.4)$ & $1.6(18 ; 1 ; 0.6)$ & $2.1(13 ; 3 ; 0.8)$ & NA & $1.6(9 ; 0 ; 0.7)$ & $2.2(5 ; 0 ; 0.6)$ & $2.0(8 ; 2 ; 0.7)$ \\
\hline $\begin{array}{l}\text { Other AES } \\
\text { habitats }\end{array}$ & $\begin{array}{l}1.9(9 ; 1 ; 0.6) \\
\mathrm{ab}\end{array}$ & $1.9(18 ; 1 ; 0.5) b$ & $2.1(13 ; 1 ; 0.9) b$ & $1.2(10 ; 1 ; 0.5)$ a & $1.3(9 ; 0 ; 0.6)$ a & $\begin{array}{l}1.4(5 ; 1 ; 0.7) \\
a b\end{array}$ & $\begin{array}{l}2.3(8 ; 0 ; 0.7) \\
b\end{array}$ \\
\hline
\end{tabular}

Table 2. Pairwise comparisons among countries of the preferences toward habitat management types: mean (\# of respondents; \# of 'Unfamiliar' option; standard deviations).

Note: these variables follow a three point scale: 1 = 'Dislike', 2 = 'Indifferent', 3 = 'Like'; different letters within a row indicate significant differences at $\mathrm{p}<0.05$. 'NA' is where no participants have provided answers. Linear woody habitat consists of hedgerows; grassy linear consists of buffer strips, grass field margins, and beetle banks; herbaceous ungrazed consists of wildflower strips; undersowing denotes undersown spring cereals; other AES habitats consist of land set aside and over winter stubbles. For detailed summaries see Appendices C\&D. 


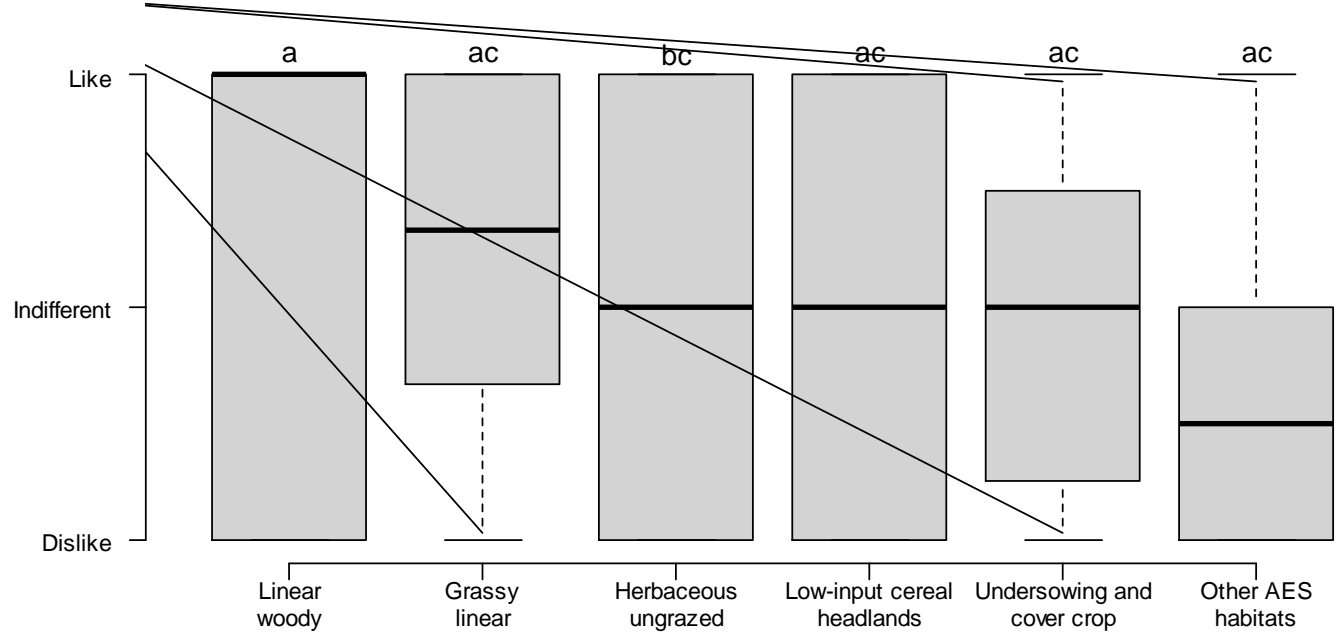

Fig 1. Boxplot of EU farmers' preferences toward habitat management types (different letters denote significant difference between two group, with $p<0.05)$. The number of respondents is 84 . The $p$ value for the Skillings-Mack test is 0.04 .

\section{3 perceptions of natural pest control service and pest damage}

The perceived importance of natural enemies for crop production was highest among Swedish and Italian farmer respondents (average 'Very important'), and lowest for Hungarian respondents ('Not as important') (Table 3). The average response from other countries was 'Important'. In terms of the most important natural enemies on farm, Dutch participants mentioned more species (average two) than German and UK (one). Insecticides were commonly used across all countries (average $80 \%$ ). The incentives to use chemicals due to a lack of natural enemies were highest among the Dutch, Polish, Swedish and UK participants (average 88\%) and were lowest among Hungarian (24\%). The number of ways used by respondents to promote natural pest control was lowest in Hungary and Poland (median zero). 


\begin{tabular}{|c|c|c|c|c|c|c|c|}
\hline & Germany & Hungary & Italy & Netherlands & Poland & Sweden & UK \\
\hline $\begin{array}{l}\text { Importance of } \\
\text { natural pest control }\end{array}$ & $\begin{array}{l}3.2(9 ; 0.8) \\
a b\end{array}$ & $2.1(18 ; 1.0)$ a & $3.3(12 ; 1.1) b$ & $\begin{array}{l}2.7(20 ; 0.7) \\
a b\end{array}$ & $2.8(9 ; 0.8) a b$ & $3.6(5 ; 0.6) b$ & $\begin{array}{l}2.8(8 ; 1.4) \\
a b\end{array}$ \\
\hline $\begin{array}{l}\text { \# of important } \\
\text { natural enemies } \\
\text { mentioned }\end{array}$ & $1.0(4 ; 0) \mathrm{ac}$ & $\begin{array}{l}2.1(15 ; 1.0) \\
a b\end{array}$ & $1.0(2 ; 0) a b c$ & $2.1(17 ; 0.7) b$ & $1.0(3 ; 0) a b c$ & $\begin{array}{l}2.0(4 ; 2.0) \\
a b c\end{array}$ & $\begin{array}{l}0.9(8 ; 0.6) \\
c\end{array}$ \\
\hline $\begin{array}{l}\text { Importance of pest } \\
\text { damage }\end{array}$ & $3.4(9 ; 0.7)$ & $3.3(18 ; 0.5)$ & $3.2(12 ; 1.0)$ & $3.0(20 ; 0.7)$ & $3.7(9 ; 0.5)$ & $3.8(5 ; 0.5)$ & $3.4(8 ; 0.8)$ \\
\hline $\begin{array}{l}\text { \# of important pests } \\
\text { mentioned }\end{array}$ & $\begin{array}{l}1.3(9 ; 0.9) \\
a\end{array}$ & $3.2(18 ; 1.0) b$ & $1.4(9 ; 1.0)$ a & $3.6(18 ; 1.2) b$ & $2.3(8 ; 0.9) a b$ & $3.0(5 ; 3.5) a b$ & $\begin{array}{l}2.1(8 ; 1.1) \\
a b\end{array}$ \\
\hline $\begin{array}{l}\text { Do you use } \\
\text { chemicals to } \\
\text { manage pests? }\end{array}$ & $0.9(8 ; 0.4)$ & $0.8(18 ; 0.4)$ & $0.5(11 ; 0.5)$ & $1.0(20 ; 0.2)$ & $0.8(10 ; 0.4)$ & $1.0(5 ; 0)$ & $0.8(8 ; 0.5)$ \\
\hline $\begin{array}{l}\text { Do you use } \\
\text { chemicals due to } \\
\text { lack of natural } \\
\text { enemies? }\end{array}$ & $\begin{array}{l}0.4(7 ; 0.5) \\
\mathrm{ab}\end{array}$ & $0.2(17 ; 0.4)$ a & $0.5(6 ; 0.5) a b$ & $0.8(19 ; 0.4) b$ & $1.0(9 ; 0) b$ & $1.0(5 ; 0) b$ & $\begin{array}{l}0.9(8 ; 0.4) \\
b\end{array}$ \\
\hline $\begin{array}{l}\text { \# of ways } \\
\text { mentioned to } \\
\text { promote natural } \\
\text { pest control }\end{array}$ & $\begin{array}{l}1.4(9 ; 0.5) \\
a\end{array}$ & $0.4(18 ; 0.6) b$ & $\begin{array}{l}0.8(13 ; 0.4) \\
a b\end{array}$ & $1.4(20 ; 0.9) \mathrm{a}$ & $0.1(9 ; 0.3) b$ & $1.4(5 ; 0.5) \mathrm{a}$ & $\begin{array}{l}1.6(8 ; 1.3) \\
a\end{array}$ \\
\hline
\end{tabular}

Table 3. Pairwise comparisons among countries of the perceptions of natural pest control service and pest damage: mean (\# of respondents; standard deviations)

Note: '\#' denotes 'number'; importance of natural pest control/ pest damage follows the codes of: 1= 'Relatively unimportant', 2='Not as important', 3='Important', 4=’'Very important'; questions follow the codes of: $0=$ 'No', 1 = 'Yes'; different letters within a row indicate significant differences at $p<0.05$.

When comparing the perceived importance of different ecosystem services and disservices towards the success/failure of crop production among the member states (Fig. 2), participants perceived natural pest control as the least important (average 'Important'), followed by three types of ecosystem disservices. Soil fertility and pollination (including self and cross pollination types) received the most importance ('Very important'). The perceived importance of natural pest control also had the largest variation (from 'Not as important' to 'Very important'), whereas the others, except for soil ('Very important'), varied from 'Important' to 'Very important'. 


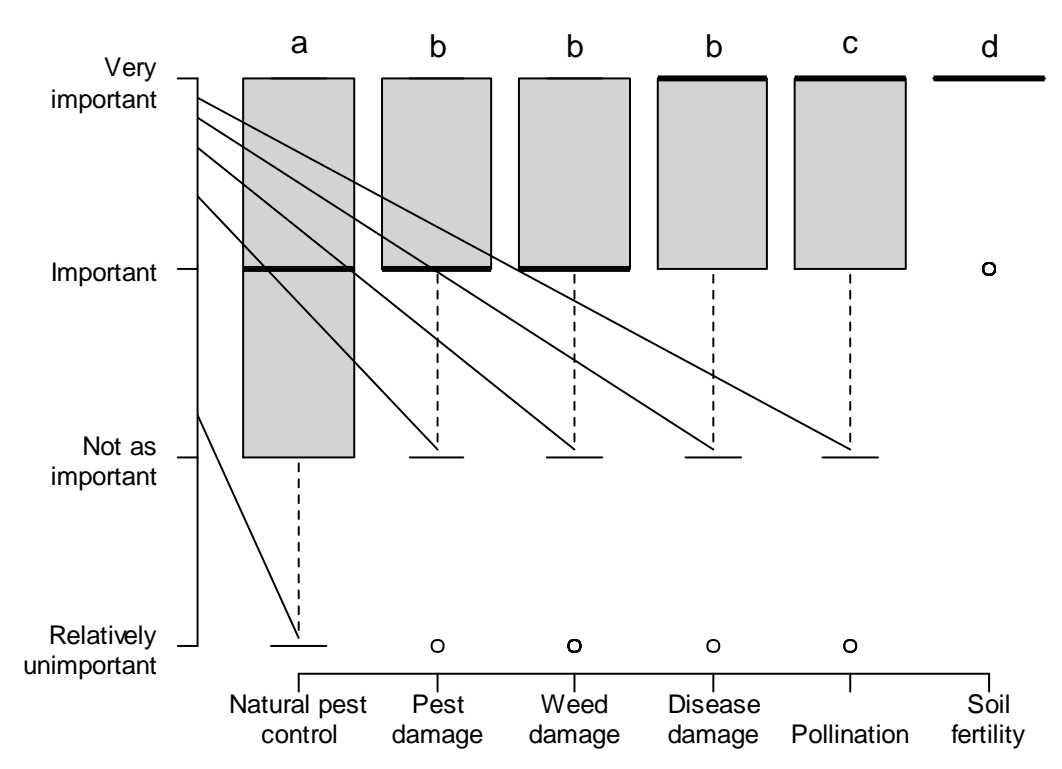

Fig 2. Boxplots of EU farmers' perceived importance of ecosystem services and disservices on the success/failure of crop production (different letters above the boxplots denote significant differences among groups, with $p<0.05)$. The number of respondents is 83 . The $p$ value for the Skillings-Mack test is $<0.00001$.

\subsection{What influences EU farmers' decision to promote natural pest control?}

The coefficients $(\beta)$ of the ordinal logistic regression models are log-transformed (base=e) odds ratios (Tables $4 \& 5)$. Odds ratios $\left(\mathrm{e}^{\beta}\right)$ are achieved by comparing the odds/likelihood that an outcome will occur given an exposure, with the odds/likelihood of outcome occurring without that exposure (Szumilas, 2010). For example, the predictor 'Importance of natural pest control' (Table 4) indicates that, the likelihood for an EU farmer to promote natural pest control when he/her view on the importance of natural pest control is 'Not as important' is 13 times higher than when the view is 'relatively not important'.

Thus, based on the 85 participants, EU farmers' decision to encourage natural pest control was positively associated with farm income and the perceived importance of natural pest control on crop production, but negatively associated with the number of perceived important pests listed, and whether a farm was located in a designated area of environmental interest (Table 4). The decision to use insecticide was positively associated with both income and a farmer's perception of the importance of pest damage on crop production (Table 5). Country effect was not significant for either model. 


\begin{tabular}{|c|c|c|c|c|}
\hline Coefficients & $\begin{array}{c}\beta \text { (standard } \\
\text { error) }\end{array}$ & $z$ value & $p$ & $\begin{array}{c}\text { Odds ratios } \\
\left(\mathrm{e}^{\beta}\right)\end{array}$ \\
\hline \multicolumn{5}{|l|}{$\begin{array}{l}\text { Importance of natural pest } \\
\text { control* }\end{array}$} \\
\hline Not as important & $2.6(1.1)$ & 2.3 & 0.02 & 13.0 \\
\hline Important & $2.9(1.1)$ & 2.7 & 0.007 & 17.7 \\
\hline Very important & $3.5(1.1)$ & 3.2 & 0.002 & 32.7 \\
\hline \# of important pests mentioned & $-0.4(0.2)$ & -2.0 & 0.05 & 0.7 \\
\hline Farm income & $0.6(0.2)$ & 3.5 & 0.0005 & 1.9 \\
\hline $\begin{array}{l}\text { In a designated area of } \\
\text { environmental interest? }\end{array}$ & $-1.5(0.6)$ & -2.4 & 0.02 & 0.2 \\
\hline
\end{tabular}

Table 4. Ordinal logistic regression results of EU farmers' decision to promote natural pest control (McFadden's Pseudo R-Square is 0.5).

Note: * Baseline category is 'Relatively unimportant'; '\#' denotes 'number'; importance of natural pest control follows the codes of: $1=$ 'Relatively unimportant', 2='Not as important', 3='Important', 4='Very important'; farm income: the average annual farm income for the last two financial years, preceding the date of the survey ( $€$, following a seven point scale: $1=$ loss, $2=1-20,000,3=20,001-40,000, \ldots, 6=80,000-100,000,7$ $=>100,000)$; questions follow the codes of: $0=$ 'No', $1=$ 'Yes'.

\begin{tabular}{|c|c|c|c|c|}
\hline Coefficients & $\begin{array}{c}\beta \text { (standard } \\
\text { error) }\end{array}$ & $z$ value & $p$ & $\begin{array}{c}\text { Odds ratios } \\
\left(e^{\beta}\right) \\
\end{array}$ \\
\hline \multicolumn{5}{|l|}{$\begin{array}{l}\text { Importance of pest } \\
\text { damage* }\end{array}$} \\
\hline Important & $1.5(1.2)$ & 1.2 & 0.2 & 4.4 \\
\hline Very important & $2.4(1.3)$ & 1.9 & 0.06 & 11.5 \\
\hline Farm income & $0.6(0.3)$ & 2.6 & 0.009 & 1.9 \\
\hline
\end{tabular}

Table 5. Ordinal logistic regression results of EU farmers' decisions to use chemical control (McFadden's Pseudo R-Square is 0.4).

Note: * Baseline category is 'Not as important'; 'Relatively unimportant' is not included because only one respondent selected this category; importance of pest damage follows the codes of: 1= 'Relatively unimportant', 2='Not as important', 3='Important', 4='Very important'; farm income: the average annual farm income for the last two financial years, preceding the date of the survey $(€$, following a seven point scale: $1=$ loss, $2=1-20,000,3=20,001-40,000, \ldots, 6=80,000-100,000,7=>100,000)$. 
The predicted probabilities of the response variables were plotted against each predictor, while keeping other predictors constant at their average values (perceived importance of natural pest control = 'Important', number of important pests mentioned $=3$, farm income $=€ 40-60,000$, whether a farm is in a designated area of environmental interests $=$ ' $N \mathrm{~N}^{\prime}$ ).

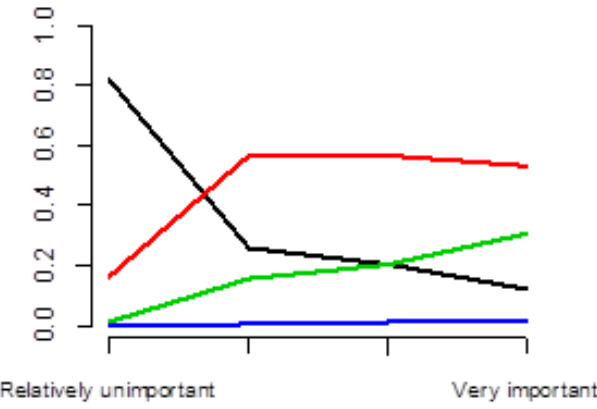

Importance of natural enemies

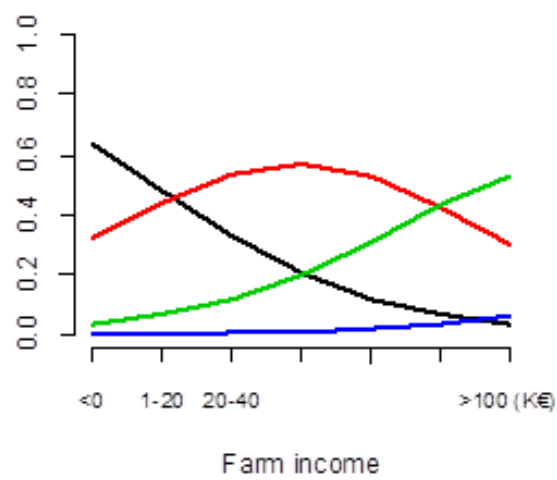

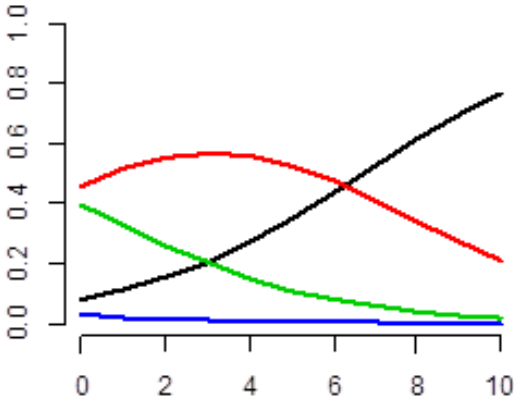

Number of pests mentioned

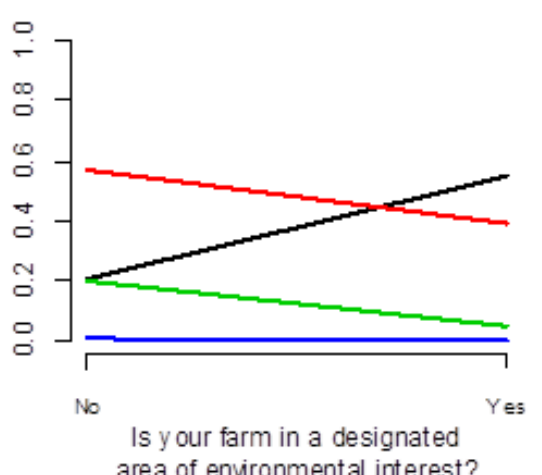

Ways to promote $=0$ Ways to promote $=1$

Ways to promote $=2$ Ways to promote $=3$

Fig 3. The predicted probabilities of EU farmers' decision to promote natural pest control in relation to each predictor, while keeping other predictors constant at their average values. For the predicted $95 \%$ confidence intervals see Appendix G. 

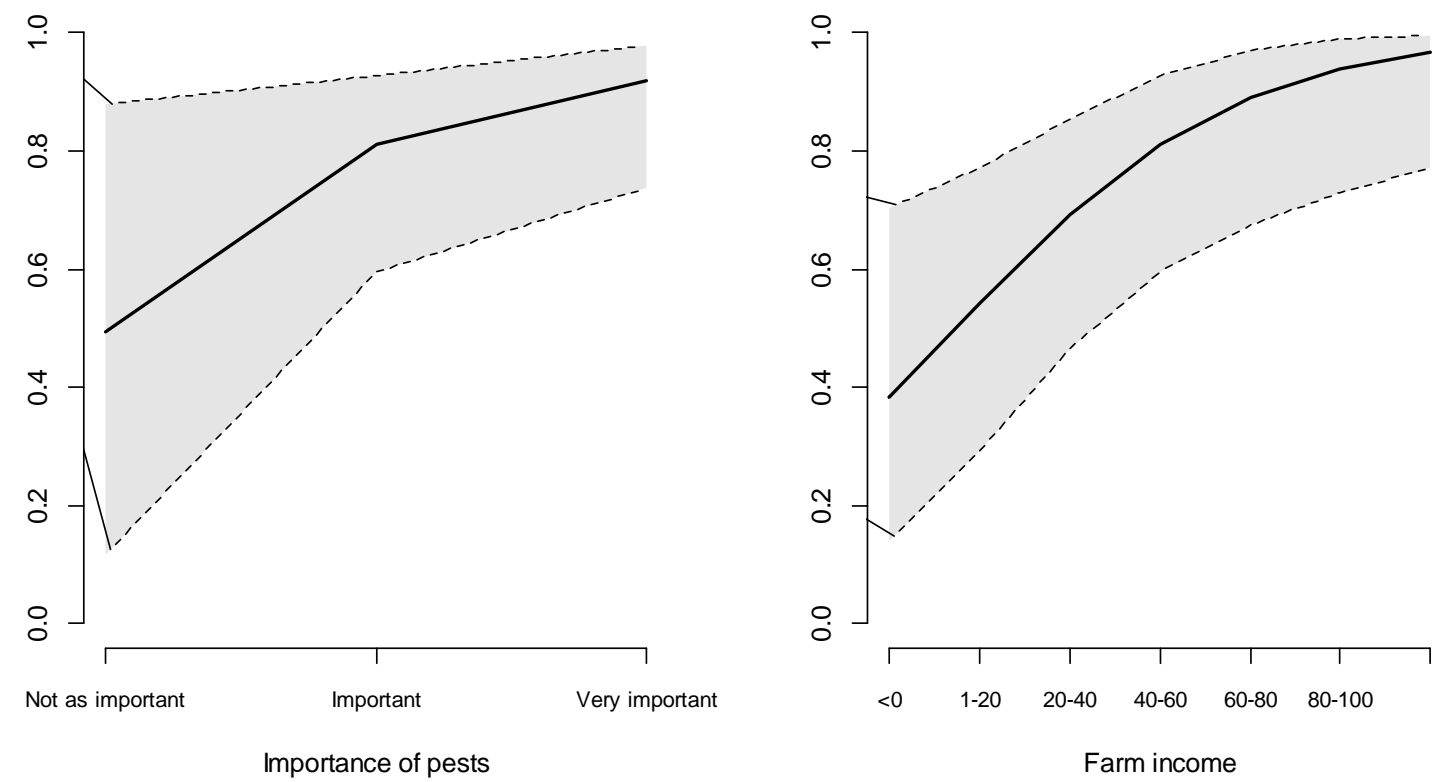

Fig 4. The predicted probabilities of EU farmers' decision to use insecticides in relation to each predictor, while keeping other predictors constant at their average values. Grey areas denote $95 \%$ confidence intervals.

Based on the farmer interviews, an increase in farm income (Fig. 3) decreases the probability that an EU farmer does not use any methods to promote natural pest control (zero method - denoted by the black line, from 64 to $4 \%$ ), whereas the probability of taking actions increase (denoted by the green line, from 4 to 53\%). Similar effects could be found for the perceived importance of natural enemies. By contrast, with an increase in the number of perceived important pests mentioned, the probability that a farmer takes actions to conserve would decrease, whereas the probability for no conservation effort increase (8 to $70 \%$ ). It is also clear that (Fig. 4), with an increase in farm income and the perceived importance of pest damage to crop production, the probability of using insecticides increases.

\section{Discussion}

Based on interviews with 85 farmers across seven EU member states, we found that their decisions on pest control practices were associated with psychological, financial, and environmental factors. For the first time, we quantified the influence of farmers' perceptions of natural pest control service and pest damage disservice on their behaviour in pest management. This is also one of the first 
studies that analysed how attitudes toward an ecosystem service would influence decision-making at an individual level (Lamarque et al., 2014; Poppenborg and Koellner, 2013).

The positive association between the perceived value of an ecosystem service (in this study, natural pest control) and decision-making in related conservation action (promoting natural pest control in the cropland) has also been illustrated in Poppenborg \& Koellner (2013). From the questionnaire design (Appendix B), a participant's evaluation of the importance of natural pest control service was based on its perceived contribution to crop production, and Fig. 2 highlights a limited recognition for this ecosystem service compared with others (e.g., soil fertility). This issue has also been revealed in other studies (e.g. Heong and Escalada, 1999; Wyckhuys and O'Neil, 2007). One possible reason is that, despite some related reviews demonstrating the contribution of crop protection by natural enemies (Letourneau et al., 2009; Symondson et al., 2002; Thies et al., 2011), there are relatively large variations among individual studies. These variations are the product of a number of factors: e.g., climate (Abbott et al., 2014), landscape structure (Chaplin-Kramer et al., 2011; Martin et al., 2013), and farm management (Zhao et al., 2015). It is thus difficult to devise an experiment that would provide sufficient, observable evidence that natural pest control would contribute to a crop production system in a certain location that matches any individual farmer's situation. This potentially decreases EU farmers' confidence towards this ecosystem service.

However, the perceived value of natural pest control could potentially be increased if other contributions by this ecosystem service were taken into account: e.g., reduction in insecticide resistance, improvement in workers' health, and protection of the wider environment (Lefebvre et al., 2015; Naranjo et al., 2015). Consequently, EU farmers' willingness to promote natural pest control would be increased.

This study revealed a negative association between the number of perceived important pest species mentioned by a farmer participant with his/her decision to promote natural pest control in the fields. The association test also showed a negative link between the perceived importance of pest damage to crop production and decisions on the conservation actions (Appendix F; Kendall's tau b test $=-0.16)$. This may further justify farmers' relatively low confidence in sufficient crop protection by natural enemies, especially when pest damage is at a high level. Indeed, limits of natural pest control under high pest damage levels have been demonstrated by field experimental studies (Collins et al., 2002). By comparison, a positive association between the perceived importance of pest damage and decision to use chemical control was revealed (Fig. 4). Since their introduction, insecticides have proved their effectiveness in controlling pests and improving crop production worldwide (Cooper and Dobson, 2007). They are also commonly used during the post-harvest 
storage phase (Waterfield and Zilberman, 2012). However, it should be noted that using chemicals does not guarantee success: failures have occurred partly due to the development of insecticide resistance in pests (Sparks and Nauen, 2015). Insecticide efficacy could also be negatively influenced by weather conditions and the timing and method of application. Nonetheless, it is economically reasonable for farmers to apply insecticides, especially when they perceive pest damage to be high (Popp et al., 2013). They would also apply insecticides for insurance purposes to reduce potential risk of crop loss by pests (Cooper and Dobson, 2007).

The negative association between the number of perceived important pest species with the decision-making on conservation, however, may also indicate that farmers have relatively low confidence that the related environmental management options could enhance natural pest control in croplands. This could be reflected by the relatively low preference levels ('Indifferent') with large variations among the semi-natural habitat management types (Fig. 1). Indeed, although mounting evidence suggests that semi-natural habitats could support natural enemies by providing food resources and shelters (Bianchi et al., 2013; Holland et al., 2016), limited studies have been conducted to show that they could enhance natural enemy densities in the adjacent crop fields and/or increase natural pest control efficacies (Dicks et al., 2016; Holland et al., 2016; Pywell et al., 2015; Straub et al., 2008).

Studies have found that farmers' perception of risk could influence their behaviour in pest control (Milne et al., 2016), and that farmers with more income are on average less risk adverse (Bar-Shira et al., 1997). This could partly explain the positive association between farm income and farmers' decision to adopt related environmental managements to promote natural pest control service (Allahyari et al., 2016; Chandran, 2014). Indeed, higher income gives farmers a greater ability to bear the risk of potential financial loss from a less effective management option. It also allows farmers to have more flexibility to invest in related technologies in the first place (e.g., by purchasing related equipment and hiring expertise) (Cullen and Warner, 2008; Lefebvre et al., 2015; Waterfield and Zilberman, 2012). More financial flexibility may also play a positive role in farmers' decision to use insecticides (Fig. 4; Anang \& Amikuzuno 2015). On the other hand, effective insecticides could help maintain or increase crop yields, thus deliver more income to the users (Cooper and Dobson, 2007; Popp et al., 2013).

Environmental factors may also influence a farmer's decision-making processes (Singh and Dhillon, 2004; Wyckhuys and O'Neil, 2010). It is not clear why an EU farmer's decision to encourage natural pest control was negatively associated with whether his/her farm was located in a designated area of environmental interest (e.g., nature reserve). One possible reason is that a farm located in such 
protected locations is potentially adjacent to already well-structured (semi-) natural habitats, thus reducing the willingness/needs of its owners to take conservation actions. Another reason could be that farm owners in these locations have specific restrictions on managing the land (JNCC, 2016).

In addition to the factors assessed in this study, many other factors may also influence farmers' behaviour in pest control. One of the most important is the individual knowledge level. Studies show that by gaining more awareness of the existence and role of natural enemies in the fields, farmers become more capable to adopt alternative pest control techniques (Segura et al., 2004; Wyckhuys and O'Neil, 2007). Other potential influences include: farmers' environmental awareness, accessibility to information, and market interventions (Lefebvre et al., 2015). Because the farmer participants in this study were involved in an agri-environmental project, they might be more aware of the natural pest control service and/or environmental protection than the general EU arable farmer population. Thus the average EU arable farmers' recognition of this ecosystem service and related conservation options might be even lower.

Compared among the seven EU countries, Hungarian participants expressed relatively low recognition of natural pest control service and low willingness to promote this ecosystem service (Table 3). This might be partly due to the less developed IPM policy compared with other countries (e.g., according to the Hungarian National Action Plan, regional/national pest forecasting systems have not been put in place; EC, 2017a; Ministry of Rural Development, 2013). Hungarian participants also showed relatively low preference for habitat management types suggested by AES (Table 2). One reason could be that as a relatively new EU member state, Hungarian farmers have less experience and/or less support historically from the government to adopt various management options. This may be reflected by the relatively low AES expenditure in Hungary among the seven countries (sixth place; Fig 1 in Batáry et al., 2015).

Although all Polish farmers interviewed agreed that the reason to use insecticides is because of a perceived lack of natural pest control in the fields, only one farmer mentioned one method to promote this ecosystem service (Table 3). This may partly result from the less developed AES policy (similar to Hungary), which constrained farmers' conservation options. In comparison, the Italian government has made extensive use of the Rural Development funds to develop AES (third place; Batáry et al., 2015; Defrancesco et al., 2008). Farmers also receive additional payments to keep detailed records of crop production (EC, 2017b). This is reflected in the participants' relatively high preferences toward various habitat management types (Table 2 ) and high recognition of natural pest control (Table 3). 
Sweden, UK, Germany and the Netherlands have relatively long histories of implementing IPM (since 1980s, 1990s, 2004, and 1990s respectively; EC, 2017b) and AES (1986, 1987, 1985, and 1981 respectively; Batáry et al., 2015), which may partly explain participants' relatively high willingness to use alternative pest control methods. In particular, Dutch participants showed a relatively good knowledge about natural pest control (indicator: number of species; Table 3). One contributing factor might be that Dutch farmers are required to record IPM measures used in their fields (EC, 2017b). The Netherlands has also developed a good extension program, where farmers and other stakeholders jointly decide on matters regarding sustainable crop protection (Barzman and Dachbrodt-Saaydeh, 2011).

Also, because of the variations in the agricultural systems and social-economic factors among EU member states, the drivers influencing a farmer's decision in pest management could differ by countries. These differences could potentially be identified with a larger sample size. Indeed, to better implement IPM and related conservation policies in the EU, more research should be conducted to compare farmers' attitudes to these aspects among the member states (Babai et al., 2015; Lefebvre et al., 2015).

\section{Conclusion}

Based on the interviews among EU arable farmers who participated in an agri-environmental project, this study analysed farmers' incentives to promote natural pest control in the fields. Although strongly encouraged under the EU IPM legislation, farmer participants expressed a relatively low recognition for this ecosystem service, and low preference towards the related AES habitat management types. On the other hand, using insecticides was a consensus among the member states. EU farmers' decision to promote natural pest control was positively associated with their attitudes toward the perceived importance of this ecosystem service on crop production. However, they expressed a relatively low confidence in the effectiveness of pest suppression by this mechanism, especially under high pest damage levels. Farmers with greater income would have more financial flexibility to adopt related conservation actions. The environment surrounding a farm may also influence its owner's willingness to promote natural pest control. More field studies should be conducted to analyse the efficacy of natural pest control and the effectiveness of related conservation management options for the major crop production systems that are relevant for the 
EU arable farmers. Future work should also explore the drivers of potential differences in farmers' uptake of these conservation actions within and between the member states.

\section{Acknowledgement}

This research received funding from the European Community's Seventh Framework Programme under grant agreement no 311781, LIBERATION Project (LInking farmland Biodiversity to Ecosystem seRvices for effective ecological intensificATION; http://www.fp7liberation.eu/). We sincerely thank all the LIBERATION collaborators who participated in collecting the survey data. We sincerely thank Erika Degani and Samuel Leigh for their assistance with the data analyses. 


\section{References}

Abbott, K.C., Harmon, J.P., Fabina, N.S., 2014. The challenge of predicting temperature effects on short-term predator--prey dynamics. Popul. Ecol. 56, 375-392.

https://doi.org/10.1007/s10144-013-0426-x

Aguilar-Fenollosa, E., Ibáñez-Gual, M.V., Pascual-Ruiz, S., Hurtado, M., Jacas, J.A., 2011. Effect of ground-cover management on spider mites and their phytoseiid natural enemies in clementine mandarin orchards (I): Bottom-up regulation mechanisms. Biol. Control 59, 158-170. https://doi.org/10.1016/j.biocontrol.2011.06.013

Allahyari, M.S., Damalas, C.A., Ebadattalab, M., 2016. Determinants of integrated pest management adoption for olive fruit fly (Bactrocera oleae) in Roudbar, Iran. Crop Prot. 84, 113-120. https://doi.org/10.1016/j.cropro.2016.03.002

Anang, B.T., Amikuzuno, J., 2015. Factors Influencing Pesticide Use in Smallholder Rice Production in Northern Ghana. Agric. For. Fish. 4, 77-82. https://doi.org/10.11648/j.aff.20150402.19

Babai, D., Tóth, A., Szentirmai, I., Biró, M., Máté, A., Demeter, L., Szépligeti, M., Varga, A., Molnár, Á., Kun, R., Molnár, Z., 2015. Do conservation and agri-environmental regulations effectively support traditional small-scale farming in East-Central European cultural landscapes? Biodivers. Conserv. 24, 3305-3327. https://doi.org/10.1007/s10531-015-0971-z

Bajwa, W.I., Kogan, M., 2002. Compendium of IPM Definitions (CID)- What is IPM and how is it defined in the Worldwide Literature? Oregon State University, Corvallis, OR 97331, USA.

Bar-Shira, Z., Just, R.E., Zilberman, D., 1997. Estimation of farmers' risk attitude: an econometric approach. Agric. Econ. 17, 211-222. https://doi.org/10.1016/S0169-5150(97)00021-2

Barzman, M., Bàrberi, P., Birch, A.N.E., Boonekamp, P., Dachbrodt-Saaydeh, S., Graf, B., Hommel, B., Jensen, J.E., Kiss, J., Kudsk, P., Lamichhane, J.R., Messéan, A., Moonen, A.-C., Ratnadass, A., Ricci, P., Sarah, J.-L., Sattin, M., 2015. Eight principles of integrated pest management. Agron. Sustain. Dev. 35, 1199-1215. https://doi.org/10.1007/s13593-015-0327-9

Barzman, M., Dachbrodt-Saaydeh, S., 2011. Comparative analysis of pesticide action plans in five European countries. Pest Manag. Sci. https://doi.org/10.1002/ps.2283

Batáry, P., Dicks, L. V., Kleijn, D., Sutherland, W.J., 2015. The role of agri-environment schemes in conservation and environmental management. Conserv. Biol. 29, 1006-1016. 
Bianchi, F.J.J.A., Mikos, V., Brussaard, L., Delbaere, B., Pulleman, M.M., 2013. Opportunities and limitations for functional agrobiodiversity in the European context. Environ. Sci. Policy 27, 223231. https://doi.org/10.1016/j.envsci.2012.12.014

Birch, A.N.E., Begg, G.S., Squire, G.R., 2011. How agro-ecological research helps to address food security issues under new IPM and pesticide reduction policies for global crop production systems. J. Exp. Bot. 62, 3251-3261. https://doi.org/10.1093/jxb/err064

Chandran, R.S., 2014. Experiences with implementation and adoption of integrated pest management in northeastern USA, in: Peshin, R., Pimentel, D. (Eds.), Integrated Pest Management: Experiences with Implementation, Global Overview. Springer Netherlands, Dordrecht, the Netherlands, pp. 37-64. https://doi.org/10.1007/978-94-007-7802-3_3

Chaplin-Kramer, R., O’Rourke, M.E., Blitzer, E.J., Kremen, C., 2011. A meta-analysis of crop pest and natural enemy response to landscape complexity. Ecol. Lett. 14, 922-32. https://doi.org/10.1111/j.1461-0248.2011.01642.x

Christensen, R.H.B., 2015a. ordinal - Regression Models for Ordinal Data. R package version 2015.628.

Christensen, R.H.B., 2015b. A Tutorial on fitting Cumulative Link Mixed Models with clmm2 from the ordinal Package. Vienna, Austria.

Christensen, R.H.B., 2015c. Analysis of ordinal data with cumulative link models - estimation with the R-package ordinal.

Collins, K.., Boatman, N.., Wilcox, A., Holland, J.., Chaney, K., 2002. Influence of beetle banks on cereal aphid predation in winter wheat. Agric. Ecosyst. Environ. 93, 337-350. https://doi.org/10.1016/\$0167-8809(01)00340-1

Cooper, J., Dobson, H., 2007. The benefits of pesticides to mankind and the environment. Crop Prot. 26, 1337-1348. https://doi.org/http://dx.doi.org/10.1016/j.cropro.2007.03.022

Crowder, D.W., Jabbour, R., 2014. Relationships between biodiversity and biological control in agroecosystems: Current status and future challenges. Biol. Control 75, 8-17. https://doi.org/10.1016/j.biocontrol.2013.10.010

Cullen, R., Warner, K.D., 2008. Economics and adoption of conservation biological control. Biol. Control 45, 272-280. https://doi.org/10.1016/j.biocontrol.2008.01.016 
Defrancesco, E., Gatto, P., Runge, F., Trestini, S., 2008. Factors Affecting Farmers? Participation in Agri-environmental Measures: A Northern Italian Perspective. J. Agric. Econ. 59, 114-131. https://doi.org/10.1111/j.1477-9552.2007.00134.x

Dicks, L. V, Wright, H.L., Ashpole, J.E., Hutchison, J., McCormack, C.G., Livoreil, B., Zulka, K.P., Sutherland, W.J., 2016. What works in conservation? Using expert assessment of summarised evidence to identify practices that enhance natural pest control in agriculture. Biodivers. Conserv. 25, 1383-1399. https://doi.org/10.1007/s10531-016-1133-7

European Commission, 2017a. National Action Plans [WWW Document]. URL https://ec.europa.eu/food/plant/pesticides/sustainable_use_pesticides/nap_en (accessed 12.18.17).

European Commission, 2017b. Overview Report on the Implementation of Member States' Measures to Achieve the Sustainable Use of Pesticides under Directive 2009/128/EC. Luxembourg.

European Union, 2009a. Directive 2009/127/EC of the European Parliament and of the Council of 21 October 2009 amending Directive 2006/42/EC with regard to machinery for pesticide application. Off. J. Eur. Union 52, 29-33.

European Union, 2009b. Directive 2009/128/EC of the European parliament and of the council of 21 October 2009 establishing a framework for community action to achieve the sustainable use of pesticides. Off. J. Eur. Union 52, 71-86.

European Union, 2009c. Regulation (EC) No 1107/2009 of the European parliament and of the council of 21 October 2009 concerning the placing of plant protection products on the market and repealing council directives 79/117/EEC and 91/414/EEC. Off. J. Eur. Union 52, 1-50.

European Union, 2009d. Regulation (EC) No 1185/2009 of the European Parliament and of the Council of 25 November 2009 concerning statistics on pesticides. Off. J. Eur. Union 52, 1-22.

Geiger, F., Bengtsson, J., Berendse, F., Weisser, W.W., Emmerson, M., Morales, M.B., Ceryngier, P., Liira, J., Tscharntke, T., Winqvist, C., Eggers, S., Bommarco, R., Pärt, T., Bretagnolle, V., Plantegenest, M., Clement, L.W., Dennis, C., Palmer, C., Oñate, J.J., Guerrero, I., Hawro, V., Aavikh, T., Thies, C., Flohre, A., Hanke, S., Fischer, C., Goedhart, P.W., Inchausti, P., 2010. Persistent negative effects of pesticides on biodiversity and biological control potential on European farmland. Basic Appl. Ecol. 11, 97-105. https://doi.org/http://dx.doi.org/10.1016/j.baae.2009.12.001 
Hallett, R.H., Bahlai, C.A., Xue, Y., Schaafsma, A.W., 2014. Incorporating natural enemy units into a dynamic action threshold for the soybean aphid, Aphis glycines (Homoptera: Aphididae). Pest Manag. Sci. 70, 879-888. https://doi.org/10.1002/ps.3674

Heong, K.L., Escalada, M.M., 1999. Quantifying rice farmers' pest management decisions: beliefs and subjective norms in stem borer control. Crop Prot. 18, 315-322. https://doi.org/10.1016/S0261-2194(99)00030-7

Holland, J.M., Bianchi, F.J., Entling, M.H., Moonen, A.-C., Smith, B.M., Jeanneret, P., 2016. Structure, function and management of semi-natural habitats for conservation biological control: a review of European studies. Pest Manag. Sci. 72, 1638-1651. https://doi.org/10.1002/ps.4318

JNCC, 2016. UK Protected Sites [WWW Document]. Jt. Nat. Conserv. Comm. URL http://jncc.defra.gov.uk/page-4 (accessed 12.28.16).

Jonsson, M., Bommarco, R., Ekbom, B., Smith, H.G., Bengtsson, J., Caballero-Lopez, B., Winqvist, C., Olsson, O., 2014. Ecological production functions for biological control services in agricultural landscapes. Methods Ecol. Evol. 5, 243-252. https://doi.org/10.1111/2041-210X.12149

Junge, X., Jacot, K.A., Bosshard, A., Lindemann-Matthies, P., 2009. Swiss people's attitudes towards field margins for biodiversity conservation. J. Nat. Conserv. 17, 150-159. https://doi.org/10.1016/j.jnc.2008.12.004

Lamarque, P., Meyfroidt, P., Nettier, B., Lavorel, S., 2014. How Ecosystem Services Knowledge and Values Influence Farmers' Decision-Making. PLoS One 9, 1-16. https://doi.org/10.1371/journal.pone.0107572

Lefebvre, M., Langrell, S.R.H., Gomez-y-Paloma, S., 2015. Incentives and policies for integrated pest management in Europe: a review. Agron. Sustain. Dev. 35, 27-45. https://doi.org/10.1007/s13593-014-0237-2

Letourneau, D.K., Jedlicka, J.A., Bothwell, S.G., Moreno, C.R., 2009. Effects of Natural Enemy Biodiversity on the Suppression of Arthropod Herbivores in Terrestrial Ecosystems. Annu. Rev. Ecol. Evol. Syst. 40, 573-592. https://doi.org/10.1146/annurev.ecolsys.110308.120320

Martin, E.A., Reineking, B., Seo, B., Steffan-Dewenter, I., 2013. Natural enemy interactions constrain pest control in complex agricultural landscapes. Proc. Natl. Acad. Sci. 110, 5534-5539. https://doi.org/10.1073/pnas.1215725110

McFadden, D., 1973. Conditional logit analysis of qualitative choice behavior, in: Zarembka, P. (Ed.), 
Frontiers in Econometrics. Academic Press, New York, pp. 105-142.

McLeod, A.I., 2011. Kendall: Kendall rank correlation and Mann-Kendall trend test. R package version 2.2.

Milne, A.E., Bell, J.R., Hutchison, W.D., van den Bosch, F., Mitchell, P.D., Crowder, D., Parnell, S., Whitmore, A.P., 2016. The Effect of Farmers' Decisions on Pest Control with Bt Crops: A Billion Dollar Game of Strategy. PLOS Comput. Biol. 11, 1-18.

https://doi.org/10.1371/journal.pcbi.1004483

Ministry of Rural Development, 2013. National Plant Protection Action Plan. Budapest.

Naranjo, S.E., Ellsworth, P.C., Frisvold, G.B., 2015. Economic Value of Biological Control in Integrated Pest Management of Managed Plant Systems. Annu. Rev. Entomol. 60, 621-645. https://doi.org/10.1146/annurev-ento-010814-021005

Parsa, S., Morse, S., Bonifacio, A., Chancellor, T.C.B., Condori, B., Crespo-Pérez, V., Hobbs, S.L.A., Kroschel, J., Ba, M.N., Rebaudo, F., Sherwood, S.G., Vanek, S.J., Faye, E., Herrera, M.A., Dangles, O., 2014. Obstacles to integrated pest management adoption in developing countries. Proc. Natl. Acad. Sci. 111, 3889-3894. https://doi.org/10.1073/pnas.1312693111

Pohlert, T., 2014. The Pairwise Multiple Comparison of Mean Ranks Package (PMCMR).

Popp, J., Pető, K., Nagy, J., 2013. Pesticide productivity and food security. A review. Agron. Sustain. Dev. 33, 243-255. https://doi.org/10.1007/s13593-012-0105-x

Poppenborg, P., Koellner, T., 2013. Do attitudes toward ecosystem services determine agricultural land use practices? An analysis of farmers' decision-making in a South Korean watershed. Land use policy 31, 422-429. https://doi.org/10.1016/j.landusepol.2012.08.007

Power, A.G., 2010. Ecosystem services and agriculture: tradeoffs and synergies. Philos. Trans. R. Soc. B 365, 2959-2971.

Pywell, R.F., Heard, M.S., Woodcock, B.A., Hinsley, S., Ridding, L., Nowakowski, M., Bullock, J.M., 2015. Wildlife-friendly farming increases crop yield: evidence for ecological intensification. Proc. R. Soc. B Biol. Sci. 282.

R Core Team, 2016. R: A Language and Environment for Statistical Computing.

Safarzoda, S., Bahlai, C.A., Fox, A.F., Landis, D.A., 2014. The role of natural enemy foraging guilds in controlling cereal aphids in Michigan wheat. PLoS One 9, e114230. 
https://doi.org/10.1371/journal.pone.0114230

Segura, H.R., Barrera, J.F., Morales, H., Nazar, A., 2004. Farmers' Perceptions, Knowledge, and Management of Coffee Pests and Diseases and Their Natural Enemies in Chiapas, Mexico. J. Econ. Entomol. 97, 1491-1499.

Singh, J., Dhillon, S.S., 2004. Agricultural Geography, 3rd ed. Tata McGraw-Hill Publishing Company Limited, New Delhi.

Sparks, T.C., Nauen, R., 2015. IRAC: Mode of action classification and insecticide resistance management. Pestic. Biochem. Physiol. 121, 122-128. https://doi.org/10.1016/j.pestbp.2014.11.014

Srisuradetchai, P., 2015. The Skillings-Mack Test Statistic for Block Designs with Missing Observations.

Stern, V., Smith, R., van den Bosch, R., Hagen, K., 1959. The integration of chemical and biological control of the spotted alfalfa aphid: The integrated control concept. Hilgardia 29, 81-101. https://doi.org/10.3733/hilg.v29n02p081

Straub, C.S., Finke, D.L., Snyder, W.E., 2008. Are the conservation of natural enemy biodiversity and biological control compatible goals? Biol. Control 45, 225-237. https://doi.org/10.1016/j.biocontrol.2007.05.013

Stutz, S., Entling, M.H., 2011. Effects of the landscape context on aphid-ant-predator interactions on cherry trees. Biol. Control 57, 37-43. https://doi.org/10.1016/j.biocontrol.2011.01.001

Symondson, W.O.C., Sunderland, K.D., Greenstone, M.H., 2002. Can Generalist Predators be Effective Biocontrol Agents? Annu. Rev. Entomol. 47, 561-594.

Szumilas, M., 2010. Explaining Odds Ratios. J. Can. Acad. Child Adolesc. Psychiatry 19, 227-229.

Thies, C., Haenke, S., Scherber, C., Bengtsson, J., Bommarco, R., Clement, L.W., Piotr, C., Dennis, C., Emmerson, M., Gagic, V., Hawro, V., Jaan, L., Weisser, W.W., Winqvist, C., Tscharntke, T., 2011. The relationship between agricultural intensification and biological control:experimental tests across Europe. Ecol. Appl. 21, 2187-2196.

Waterfield, G., Zilberman, D., 2012. Pest Management in Food Systems: An Economic Perspective. Annu. Rev. Environ. Resour. 37, 223-245. https://doi.org/10.1146/annurev-environ-040911105628 
Wyckhuys, K.A.G., O'Neil, R.J., 2010. Social and ecological facets of pest management in Honduran subsistence agriculture: implications for IPM extension and natural resource management. Environ. Dev. Sustain. 12, 297-311. https://doi.org/10.1007/s10668-009-9195-2

Wyckhuys, K.A.G., O’Neil, R.J., 2007. Local agro-ecological knowledge and its relationship to farmers' pest management decision making in rural Honduras. Agric. Human Values 24, 307-321. https://doi.org/10.1007/s10460-007-9068-y

Zhang, H., Garratt, M.P.D., Bailey, A., Potts, S.G., Breeze, T., 2018. Economic valuation of natural pest control of the summer grain aphid in wheat in South East England. Ecosyst. Serv. 30, 149-157. https://doi.org/10.1016/J.ECOSER.2018.02.019

Zhao, Z.-H., Hui, C., He, D.-H., Li, B.-L., 2015. Effects of agricultural intensification on ability of natural enemies to control aphids. Sci. Rep. 5, 8024. 


\section{Appendix A. Type of crops grown by farmer participants}

\begin{tabular}{|c|c|c|}
\hline Crops & $\begin{array}{c}\text { Number of farmers that } \\
\text { grow this crop }\end{array}$ & Main pollination types \\
\hline Wheat & 84 & Wind \\
\hline Maize & 38 & Wind \\
\hline Sugar beet & 36 & Self \\
\hline Oilseed & 30 & Animal \\
\hline Barley & 28 & Wind \\
\hline Potato & 19 & Self \\
\hline Sunflower & 17 & Animal \\
\hline Onion & 15 & Self \\
\hline Soy & 14 & Wind \\
\hline Rye & 10 & Wind \\
\hline Triticale & 9 & Wind \\
\hline Alfafa & 7 & Animal \\
\hline Bean & 5 & Animal \\
\hline Grass & 5 & Wind \\
\hline Oat & 4 & Wind \\
\hline Carrot & 4 & Self \\
\hline Chicory & 3 & Animal \\
\hline Lupine & 1 & Animal \\
\hline Pulse & 1 & Animal \\
\hline Pea & 1 & Wind \\
\hline Poppy & 1 & Animal \\
\hline Clover & 1 & Animal \\
\hline Fescue & 1 & Wind \\
\hline Asparagus & 1 & Self \\
\hline Olive & 1 & Wind \\
\hline Wine grape & 1 & Wind \\
\hline
\end{tabular}




\section{Appendix B. LIBERATION farmer interview}

\section{a. Some questions about your farm}

1. What was your total agricultural area in 2013 , excluding water, woodland and hard standing?

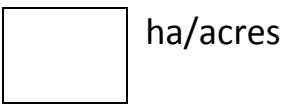

2. How much of this agricultural area was ...? Owned $\square$ Rented $\square$ Contracted

3. Which of the following best describes your farm? Please tick
Cereals
General cropping
Lowland grazing livestock
Horticulture
LFA grazing livestock
Pigs or poultry Mixed, unclassified

4. Please provide details of a typical rotation (or rotations, up to three) for your farm. There is no requirement to complete all the rows and columns, e.g. if a typical rotation is only four or five years.

\begin{tabular}{|l|l|l|l|l|l|l|}
\hline Crop 1 & Crop 2 & Crop 3 & Crop 4 & Crop 5 & Crop 6 & Crop 7 \\
\hline & & & & & & \\
\hline & & & & & & \\
\hline & & & & & & \\
\hline
\end{tabular}

5. Please provide details on the area and yields of the crops that you grow.

\begin{tabular}{|l|l|l|l|l|l|}
\hline Crops & $\begin{array}{l}\text { Approximate } \\
\text { area totals } \\
\text { (ha/ac) }\end{array}$ & $\begin{array}{l}\text { Approximate } \\
\text { yields } \\
\text { (t/ha or t/ac) }\end{array}$ & $\begin{array}{l}\text { Minimum yield } \\
\text { in last 10 years }\end{array}$ & $\begin{array}{l}\text { Maximum yield } \\
\text { in last 10 years }\end{array}$ & Market \\
\hline e.g. wheat & 60 ha & $8 \mathrm{t} / \mathrm{ha}$ & $6 \mathrm{t} / \mathrm{ha}$ & $8.5 \mathrm{t} / \mathrm{ha}$ & $\begin{array}{l}\text { Milling } \\
\text { (contract) }\end{array}$ \\
\hline 1. & & & & & \\
\hline 2. & & & & & \\
\hline 3. & & & & & \\
\hline 4. & & & & & \\
\hline 5. & & & & & \\
\hline 6. & & & & & \\
\hline
\end{tabular}

6. How would you describe the soils on your farm? Please tick one box from Row $6 a$ and one box from Row 6b.

$\begin{array}{lcl}\text { Row 6a } & \text { Light } & \text { Medium } \square \text { Heavy } \square \text { Seat } \square \text { Sand } \square \text { Clay } \square \text { Silt } \square \text { Loam } \square \\ \text { Row 6b Chalk } \square\end{array}$

7. What tillage practices do you currently adopt? Please tick all that apply

\begin{tabular}{|l|l|l|}
\hline Type & Please tick & Frequency, e.g. annually, one year in five \\
\hline Deep cultivation & & \\
\hline Shallow cultivation & & \\
\hline Zero (no) tillage & & \\
\hline Other, please state & & \\
\hline
\end{tabular}


b. Some questions about environmental features on your farm and their importance

1. Is your farm in a protected or designated area? Please tick

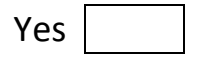

No

If yes, please state which ones. For example, National Park or Nature Reserve

2. If you are in a protected or designated area, do you feel that:

(i) the environment within and around your farm has improved as a result? Please tick the most appropriate option

Strongly Agree $\square$ Agree $\square$ Neither Agree nor Disagree $\square$ Disagree $\square$ Strongly Disagree

(ii) the productivity of your farm has improved as a result? Please tick the most appropriate option

Strongly Agree $\square$ Agree $\square$ Neither Agree nor Disagree $\square$ Disagree $\square$ Strongly Disagree

3. What environmental features do you have on your farm?

\begin{tabular}{|l|l|l|}
\hline Features & Please tick & Please specify area/length/number as appropriate \\
\hline Woodland & & \\
\hline Hedges & & \\
\hline Ditches & & \\
\hline Ponds & & \\
\hline River/stream & & \\
\hline Other, please state & & \\
\hline
\end{tabular}

4. Are you in a scheme to protect/manage these features? Please tick

Yes

No

If yes, please state which ones, the area of land entered in each, and year of entry

\begin{tabular}{|l|l|l|}
\hline Scheme & Area entered (ha/acres)/Number & Year of entry \\
\hline & & \\
\hline & & \\
\hline & & \\
\hline & & \\
\hline
\end{tabular}

5. If you are in a scheme, do you feel that:

(i) the environment within and around your farm has improved as a result? Please tick the most appropriate option

Strongly Agree $\square$ Agree $\square$ Neither Agree nor Disagree $\square$ Disagree $\square$ Strongly Disagree

(ii) the productivity of your farm has improved as a result? Please tick the most appropriate option 
Strongly Agree Agree Neither Agree nor Disagree Disagree Strongly Disagree

6. Are you a member of an environmental conservation body? Please tick. Yes No If yes, please state which ones:

\section{c. Some questions about the experimental work taking place on your and other EU farms}

For the following options, please consider what consequences you foresee as a result of their implementation, what are the potential advantages, what are the potential disadvantages?

\section{Rotation (UK, Poland, Germany, Italy)}

Imagine you are advised to adopt a crop rotation which in addition to winter cereals must incorporate some spring cropping (e.g. oilseed, protein or root crops) and legume (e.g. winter vetch) or brassica (e.g. mustard) covers prior to those crops.

What advantages can you think of regarding this option?

What disadvantages can you think of regarding this option?

\section{Crop establishment with reduced tillage (Germany, Italy)}

Imagine you are advised to establish your crops using zero tillage.

What advantages can you think of regarding this option? 


\section{Mixed cropping (Poland, Germany)}

Imagine you are advised to adopt mixed cropping within your rotation, for example, a combination of winter cereals (e.g. wheat, triticale and rye) grown in one field or a legume (e.g. lupine) and winter cereal or oilseed crop combined.

What advantages can you think of regarding this option?

What disadvantages can you think of regarding this option?

\section{Set-aside (whole field) (Hungary)}

Imagine you are advised to set aside a field for three years. You are allowed to sow it with a perennial forage legume such as alfalfa/lucerne which can be mown mid-summer but you cannot undertake any other crop management on the field.

What advantages can you think of regarding this option?

What disadvantages can you think of regarding this option?

\section{(Set-aside (field margin) (Netherlands)}

Imagine you are advised to establish a 3-5m wide margin at a field edge by sowing a mixture of perennial forb (flower and herb) and grass species. The vegetation may not be treated with pesticides with the exception of patch-wise application to problem weeds (Rumex obtusifolius, Urtica dioica, Cirsium arvense). The strips must be mown at least once a year and the cuttings need to be removed. It is allowed to drive on the perennial strips with farming machinery.

What advantages can you think of regarding this option?

What disadvantages can you think of regarding this option? 
Hedgerow (Italy, UK)

Imagine you have a long established hedgerow adjacent to your arable fields. It may contain gaps, be dense or sparse in places, consist of a single species or be a complex hedgerow composed of several tree and shrub species.

What advantages can you think of regarding hedges and different hedge compositions?

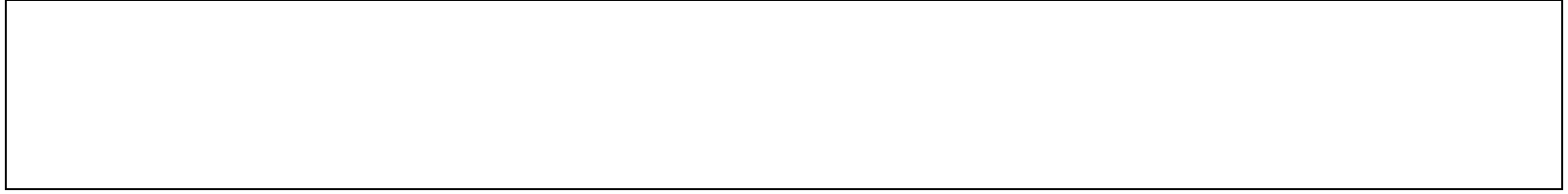

What disadvantages can you think of regarding hedges and different hedge compositions?

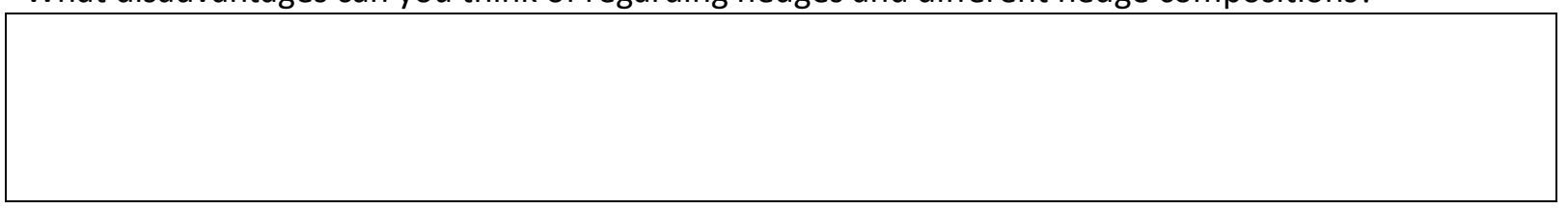

And now a different type of decision, an investment decision

For this option you must consider investing in a new piece of machinery, for example a more powerful tractor than the one you currently have available.

What is the maximum you would be prepared to invest?

What would be your desired rate of return from such an investment?

How soon would you require a return from your investment?

$€$

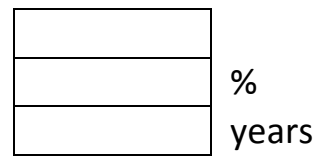

What advantages can you think of regarding this investment?

What disadvantages can you think of regarding this investment?

d. Some questions about your objectives and the factors that influence your decision making

1. What objectives do you have for your business? Can you rank these in order of importance, with

1. being most important? (Prompt: improve profit, turnover, expand business, wind down business, switch enterprises (add/remove an enterprise) 


\begin{tabular}{|l|c|}
\hline Objective & Rank \\
\hline & \\
\hline & \\
\hline & \\
\hline & \\
\hline
\end{tabular}

2. What are the key influences on your businesses? Can you rank these in order of importance, with 1. being most important? (Prompt : Policy, economics, soil, climate)

\begin{tabular}{|l|c|}
\hline Influence & Rank \\
\hline & \\
\hline & \\
\hline & \\
\hline & \\
\hline
\end{tabular}

3. Who influences your business the most? Can you rank these in order of importance, with 1 . being most important? (Prompt: Government, government agency, environmental NGOs, bank, business partner, owner, family, neighbours,)

\begin{tabular}{|l|c|}
\hline Influence & Rank \\
\hline & \\
\hline & \\
\hline & \\
\hline & \\
\hline
\end{tabular}

4. What objectives do you have for yourself, beyond farming? Can you rank these in order of importance, with 1. being most important? (Prompt: lifestyle, status, free time, retirement)

\begin{tabular}{|l|c|}
\hline Objectives & Rank \\
\hline & \\
\hline & \\
\hline & \\
\hline & \\
\hline
\end{tabular}

\section{e. Some questions about possible farm business objectives and your preferences}

\section{Farm Business Income ( $€$ )}

Specifically consider the INCOME generated by your farm. Decide the highest possible and lowest possible amount of income (that would not cause you to give up farming) using the following definition: Crop enterprise output + single farm payment + agri-environment payments + other agricultural grants and subsidies + land-based diversification income - variable costs - fixed costs

\begin{tabular}{|l|l|l|}
\hline Lowest possible income & Highest possible income \\
\hline
\end{tabular}

\section{Absolute variation in Farm Business Income (€)}

Consider your willingness to deal with about plus or minus variation in your yearly income from farming. If you are prepared to cope with a widely varying income on the chance that some years will be very good, while other years will be very bad, then the absolute deviation in Farm Business 
Income that you envisage will be larger than if you would rather have an income that is more constant but potentially lower.

Please indicate your likelihood of investing in management options/crops, which generate income that is...

high above average in some years, and high below average in other years

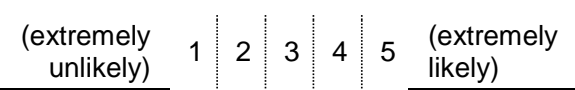

fairly above average in some years, and fairly below average in other years

slightly above average in some years, and slightly below average in other years

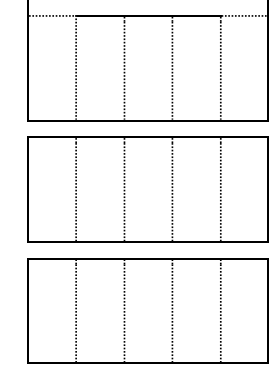

Please indicate your feeling about how risky it is to invest in management options/crops, which generate income that is...

high above average in some years, and high below average in other years

fairly above average in some years, and fairly below average in other years

slightly above average in some years, and slightly below average in other years

$$
\begin{array}{cc:c:c:c:cl}
\begin{array}{c}
\text { (not at all } \\
\text { risky) }
\end{array} & 1 & 2 & 3 & 4 & 5 & \begin{array}{l}
\text { (extremely } \\
\text { risky) }
\end{array} \\
\hline
\end{array}
$$

\section{Number of different crop types to manage}

Consider the COMPLEXITY OF MANAGEMENT involved with growing different numbers of crops simultaneously (i.e. within one harvest year). Decide the most preferred and least preferred NUMBER of crops to grow on your farm (a list of crops is provided as guidance):

\begin{tabular}{|l|l|l|l|}
\hline Most preferred number of crops & & Least preferred number of crops & \\
\hline
\end{tabular}

\begin{tabular}{|lll|}
\hline Milling wheat & Oilseed rape & Sugar beet \\
Feed wheat & Linseed & Potatoes \\
Malting barley & Peas & Field scale vegetables, please specify \\
Feed barley & Beans & Other, please specify \\
\hline
\end{tabular}




\section{Number of different environmental management practices adopted}

Consider the COMPLEXITY OF MANAGEMENT involved with managing environmental features on your farm. Decide the most preferred and least preferred number of environmental management practices to adopt on your farm using the categories listed:

Most preferred number of options Least preferred number of options

Please also indicate the options you like, those you are indifferent to, those you are unfamiliar with and those you dislike.

\begin{tabular}{|l|l|l|l|l|}
\hline & Like & Indifferent & Dislike & Unfamiliar \\
\hline Land set aside & & & & \\
\hline Crop rotation & & & & \\
\hline Mixed cropping & & & & \\
\hline Cover crop & & & & \\
\hline Overwintered stubbles & & & & \\
\hline Undersown spring cereals & & & & \\
\hline Erosion management (interventions) & & & & \\
\hline Conservation headlands & & & & \\
\hline Field corner management & & & & \\
\hline Buffer strips & & & & \\
\hline Grass field margins & & & & \\
\hline Wildflower strips & & & & \\
\hline Beetle banks & & & & \\
\hline Hedgerow management & & & & \\
\hline Ditch management & & & & \\
\hline Protection of in-field trees & & & & \\
\hline Management of woodland edges & & & & \\
\hline
\end{tabular}

\section{f. Some questions regarding your understanding of the services that the natural environment} can provide

1. Relative to each other how important are the following for determining whether you have a satisfactory or poor crop?

\begin{tabular}{|l|l|l|l|l|}
\hline & $\begin{array}{l}\text { Very } \\
\text { important }\end{array}$ & Important & $\begin{array}{l}\text { Not as } \\
\text { important }\end{array}$ & $\begin{array}{l}\text { Relatively } \\
\text { unimportant }\end{array}$ \\
\hline Soil fertility & & & & \\
\hline Water availability & & & & \\
\hline Amount of weed presence & & & & \\
\hline Amount of pest damage & & & & \\
\hline Amount of disease damage & & & & \\
\hline Regulation of pests by their natural enemies & & & & \\
\hline Pollination & & & & \\
\hline
\end{tabular}


2. Do you have problems with soil structure?

3. Do you have problems with soil erosion?

4. Do you have problems with soil Too much water storage?

water

5. Do you have problems with soil nutrient availability?

6. Do you believe healthy soil biology can improve soil productivity?

\begin{tabular}{|c|c|}
\hline Yes & No \\
\hline Yes & No \\
\hline Both & No \\
\hline Yes & No \\
\hline Yes & No \\
\hline
\end{tabular}

7. Do you do anything to encourage soil biology? Please state what

E.g. minimum/zero tillage; organic matter incorporation; reduced pesticide use

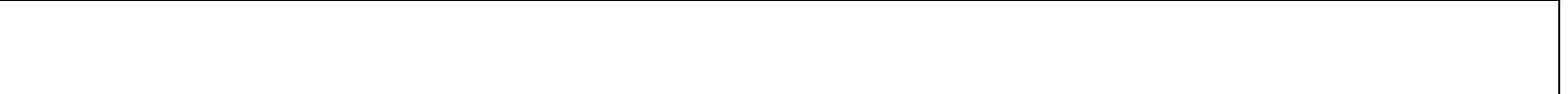

8. If you don't would you be averse to adopting?

Yes

No

Please explain your answer

\section{$\underline{\text { Weeds }}$}

9. What weeds are most problematic for your crop productivity? Please state

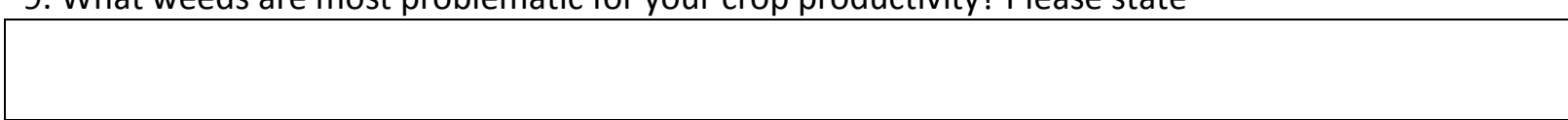

10. Do you use agrochemicals to manage these weeds?

Yes

No

11. Do you use any other forms of control?

E.g. through use of crop rotation; differing crop establishment techniques; mechanical weeding; other, please state

other, please state

12. If you don't would you be averse to adopting?

Yes

No

Please explain your answer

\section{$\underline{\text { Pests }}$}

13. What pests are most responsible for damage to your crops? Please state

14. Do you use agrochemicals to manage these crop pests?

15. Do you spray because you perceive a lack of natural enemies?

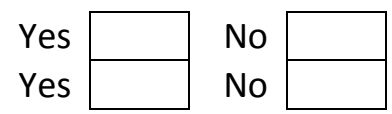


16. What are the most important biological control agents, e.g. natural enemies? Please state

17. Do you do anything to encourage these natural enemies?

E.g. Restrict pesticide application; provide habitat for beneficial species; provide nesting and/or overwintering sites; release natural enemies; other, please state

\begin{tabular}{|l|}
\hline 18. If you don't would you be averse to adopting? \\
Please explain your answer \\
\hline
\end{tabular}

\section{Diseases}

19. What diseases are most responsible for damage to your crops? Please state

(19. What diseases are most responsible for damage to your crops? Please state

20. Do you use agrochemicals to manage these diseases?

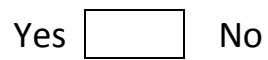

21. Do you use any other forms of control?

E.g. through use of crop rotation; variety choice; harvest to sowing interval; clean seed bed; other, please state

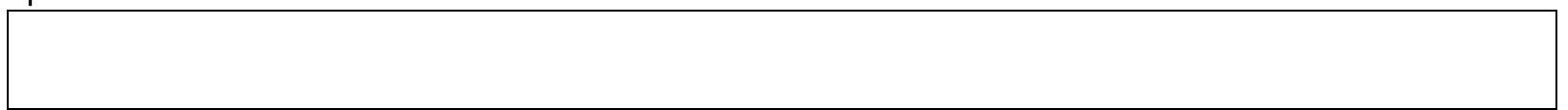

22. If you don't would you be averse to adopting?

Yes

No

Please explain your answer

\section{Pollination}

23. Is lack of pollination an issue?

24. How much do you believe your yield is affected by pollination?

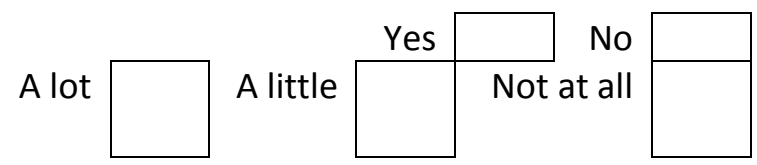

25. Which of your crops are pollinated party or wholly? Please state 
27. Do you do anything to improve pollination/encourage pollinators?

E.g. Rent beehives; restrict pesticide application; provide habitat for pollinators, i.e. wildflower strip; provide nesting and/or overwintering sites; other, please state

28. If you don't would you be averse to adopting?

Yes

No

Please explain your answer

29. Do you agree that: "it is worth reducing intensity of production and yield today to obtain economic benefits in the future". Please tick the most appropriate option that reflects your response
Strongly Agree
Agree
Neither Agree nor Disagree
Disagree
Strongly Disagree

\section{g. Some questions about you and your farm business}

1. What is your role on the farm? Please tick.
Owner
Tenant
Manager
Other, please state

2. How many years have you worked in farming? years

3 Do you work exclusively on the farm? Please tick

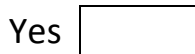

No

4. How many full time equivalent staff work on the farm, including you and paid and unpaid family members?

5. How many seasonal workers do you employ?

$\square$ Over what period?

6. Have you identified a successor? Please tick.

Yes

Possibly

No

7. In what proportion do the following sources of revenue contribute to your business?

\begin{tabular}{|l|l|}
\hline Revenue source & Contribution (\%) \\
\hline Agricultural output & \\
\hline Agri-environment income & \\
\hline Single Payment Scheme & \\
\hline Other income, please state (e.g. diversification) & \\
\hline
\end{tabular}

8. Please indicate (by tick) your average farm income in your last two financial years using the categories below:

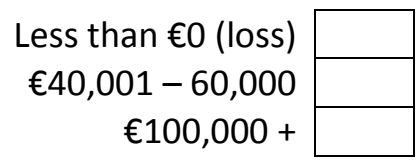

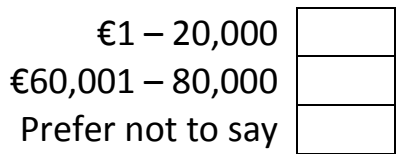

$€ 20,001-40,000$

$€ 80,001-100,000$ 


\section{Appendix C}

Farmer participants' preferences toward environmental management practices among seven European Union member states: mean (number of respondents; number of 'Unfamiliar' option; standard deviations).

\begin{tabular}{|c|c|c|c|c|c|c|c|c|}
\hline Habitats & Practices & Germany & Hungary & Italy & Netherlands & Poland & Sweden & UK \\
\hline Linear woody & Hedgerow & $2.6(9 ; 0 ; 0.9)$ & $1.5(18 ; 0 ; 0.7)$ & $2.8(13 ; 2 ; 0.4)$ & NA & $1.6(8 ; 1 ; 1.0)$ & $2.4(5 ; 0 ; 0.9)$ & $2.9(8 ; 0 ; 0.4)$ \\
\hline \multirow{3}{*}{ Grassy linear } & Buffer strips & $2.3(9 ; 0 ; 1.0)$ & $1.8(18 ; 0 ; 0.7)$ & $2.8(13 ; 1 ; 0.4)$ & $3.0(1 ; 0 ; 0)$ & $1.2(9 ; 3 ; 0.4)$ & $2.8(5 ; 0 ; 0.4)$ & $2.8(8 ; 0 ; 0.7)$ \\
\hline & Grass field margins & $1.8(8 ; 0 ; 1.0)$ & $1.8(18 ; 0 ; 0.7)$ & $2.8(13 ; 1 ; 0.6)$ & $2.5(18 ; 2 ; 0.8)$ & $1.9(9 ; 0 ; 1.1)$ & NA & $2.4(8 ; 0 ; 1.0)$ \\
\hline & Beetle banks & $1.8(8 ; 0 ; 0.9)$ & $1.9(18 ; 0 ; 0.8)$ & $2.1(13 ; 2 ; 0.8)$ & NA & $1.7(10 ; 3 ; 1.0)$ & NA & $2.0(8 ; 1 ; 1.0)$ \\
\hline $\begin{array}{l}\text { Herbaceous } \\
\text { ungrazed }\end{array}$ & Wildflower strips & $2.3(9 ; 0 ; 1.0)$ & $1.8(18 ; 0 ; 0.7)$ & $1.4(13 ; 1 ; 0.7)$ & $1.9(20 ; 3 ; 0.9)$ & $1.4(10 ; 3 ; 0.8)$ & NA & $2.3(8 ; 0 ; 1.0)$ \\
\hline $\begin{array}{l}\text { Low-input cereal } \\
\text { headlands }\end{array}$ & Conservation headlands & $2.3(8 ; 0 ; 0.9)$ & $1.7(18 ; 1 ; 0.7)$ & $2.6(13 ; 4 ; 0.7)$ & NA & $2.0(9 ; 2 ; 1.0)$ & NA & $2.0(7 ; 0 ; 1.0)$ \\
\hline \multirow{2}{*}{$\begin{array}{l}\text { Undersowing and } \\
\text { cover crops }\end{array}$} & Cover crop & $2.6(8 ; 0 ; 0.5)$ & $1.7(18 ; 0 ; 0.7)$ & $2.1(13 ; 4 ; 0.9)$ & NA & $1.5(8 ; 0 ; 0.8)$ & $2.6(5 ; 0 ; 0.5)$ & $2.3(8 ; 0 ; 0.7)$ \\
\hline & Undersown spring cereals & $1.3(8 ; 2 ; 0.8)$ & $1.6(18 ; 1 ; 0.7)$ & $2.3(13 ; 1 ; 1.0)$ & NA & $1.8(9 ; 0 ; 1.0)$ & $1.8(5 ; 0 ; 0.8)$ & $1.2(8 ; 3 ; 0.4)$ \\
\hline \multirow{2}{*}{$\begin{array}{l}\text { Other AES } \\
\text { habitats }\end{array}$} & Land set aside & $2.0(9 ; 0 ; 1.0)$ & $2.3(18 ; 0 ; 0.9)$ & $1.8(13 ; 1 ; 1.0)$ & $1.2(20 ; 1 ; 0.5)$ & $1.1(9 ; 0 ; 0.3)$ & $1.6(5 ; 0 ; 0.9)$ & $2.0(7 ; 0 ; 1.0)$ \\
\hline & Over winter stubbles & $1.6(8 ; 1 ; 1.0)$ & $1.5(18 ; 1 ; 0.5)$ & $2.2(12 ; 0 ; 0.8)$ & NA & $1.2(9 ; 0 ; 0.7)$ & $1.3(5 ; 1 ; 0.5)$ & $2.6(8 ; 0 ; 0.7)$ \\
\hline \multirow{6}{*}{ Other practices } & Crop rotation & $2.8(9 ; 0 ; 0.7)$ & $3.0(18 ; 0 ; 0)$ & $2.9(13 ; 0 ; 0.3)$ & $2.8(19 ; 0 ; 0.5)$ & $2.8(10 ; 0 ; 0.6)$ & $2.6(5 ; 0 ; 0.9)$ & $2.9(8 ; 0 ; 0.4)$ \\
\hline & Mixed cropping & $1.6(8 ; 0 ; 0.7)$ & $1.8(18 ; 0 ; 0.8)$ & $2.8(12 ; 1 ; 0.6)$ & $1.9(20 ; 11 ; 0.8)$ & $2.4(10 ; 0 ; 0.8)$ & NA & $3.0(8 ; 1 ; 0)$ \\
\hline & Field corner management & $1.8(8 ; 0 ; 0.7)$ & $2.1(18 ; 0 ; 0.8)$ & $2.9(13 ; 0 ; 0.3)$ & $1.8(20 ; 14 ; 1.0)$ & $1.5(9 ; 1 ; 0.8)$ & NA & $2.9(8 ; 0 ; 0.4)$ \\
\hline & Ditch management & $2.5(8 ; 0 ; 0.9)$ & $2.5(18 ; 0 ; 0.7)$ & $2.8(13 ; 1 ; 0.4)$ & $1.9(20 ; 3 ; 0.9)$ & $2.4(10 ; 0 ; 0.8)$ & NA & $2.7(7 ; 0 ; 0.5)$ \\
\hline & Protection of in-field trees & $2.1(8 ; 1 ; 1.1)$ & $2.7(18 ; 0 ; 0.5)$ & $2.2(13 ; 2 ; 0.8)$ & NA & $2.1(9 ; 0 ; 0.9)$ & $2.4(5 ; 0 ; 0.9)$ & $2.3(8 ; 0 ; 0.7)$ \\
\hline & Management of woodland edges & $2.5(9 ; 1 ; 0.9)$ & $2.6(18 ; 1 ; 0.5)$ & $2.6(13 ; 2 ; 0.5)$ & NA & $2.0(9 ; 1 ; 0.9)$ & NA & $2.5(8 ; 0 ; 0.8)$ \\
\hline
\end{tabular}

Note: The environmental management practices were grouped into various habitat management types, followed by a review of Holland et al. (2016). 'Other practices' were the ones not included in this review, thus not included in the manuscript. 


\section{Appendix D}

Boxplot of EU farmers' preferences toward habitat management types. The number of respondents is 84 .

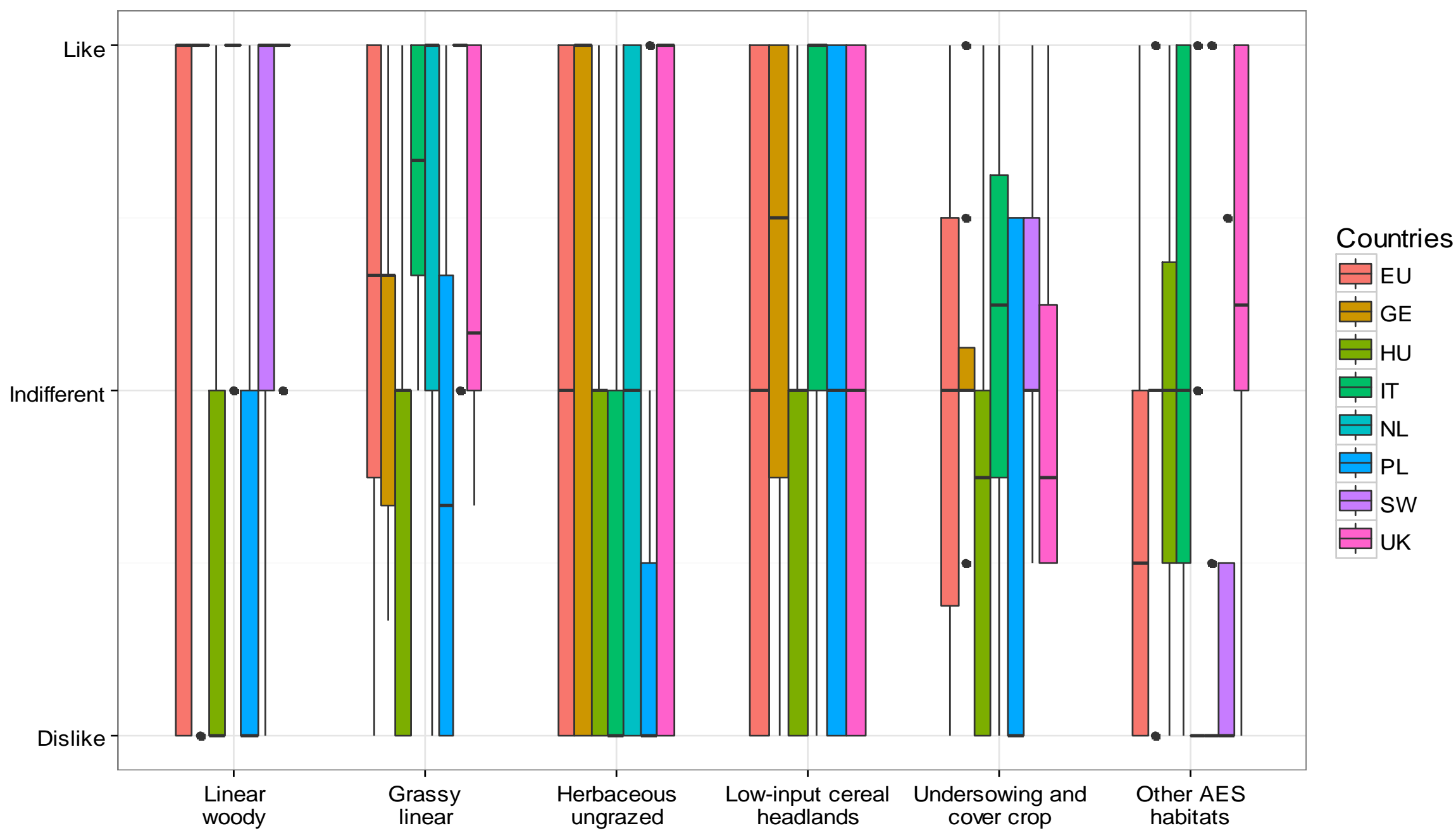




\section{Appendix E}

Methods to promote natural pest control and the related number of times mentioned by farmer participants from seven European Union member states

\begin{tabular}{|c|c|c|c|c|c|c|c|c|c|c|c|}
\hline \multirow[t]{2}{*}{ Germany } & $\begin{array}{l}\text { Reduce } \\
\text { pesticide }\end{array}$ & $\begin{array}{l}\text { Timing of } \\
\text { pesticide }\end{array}$ & $\begin{array}{l}\text { Intensive } \\
\text { protection } \\
\text { methods } \\
\end{array}$ & Provide habitat & Flower strips & $\begin{array}{l}\text { Cover crops in } \\
\text { winter }\end{array}$ & Soil biota & & & & \\
\hline & 3 & 2 & 1 & 4 & 1 & 1 & 1 & & & & \\
\hline \multirow[t]{2}{*}{ Hungary } & $\begin{array}{c}\text { Provide } \\
\text { bird } \\
\text { habitat }\end{array}$ & & & & & & & & & & \\
\hline & 6 & & & & & & & & & & \\
\hline \multirow{2}{*}{ Italy } & $\begin{array}{c}\text { Reduce } \\
\text { pesticide }\end{array}$ & Provide habitat & None & & & & & & & & \\
\hline & 9 & 2 & 1 & & & & & & & & \\
\hline \multirow[t]{2}{*}{ Netherlands } & $\begin{array}{l}\text { Reduce } \\
\text { pesticide }\end{array}$ & $\begin{array}{l}\text { Avoid pesticide } \\
\text { resistance }\end{array}$ & $\begin{array}{l}\text { Provide bird } \\
\text { habitat }\end{array}$ & Rotation & $\begin{array}{l}\text { Bring natural } \\
\text { enemies }\end{array}$ & $\begin{array}{l}\text { Margin/flower } \\
\text { strip } \\
\text { management }\end{array}$ & None & & & & \\
\hline & 14 & 1 & 1 & 1 & 4 & 7 & 2 & & & & \\
\hline \multirow[t]{2}{*}{ Poland } & $\begin{array}{c}\text { Reduce } \\
\text { pesticide }\end{array}$ & & & & & & & & & & \\
\hline & 4 & & & & & & & & & & \\
\hline \multirow[t]{2}{*}{ Sweden } & $\begin{array}{c}\text { Reduce } \\
\text { pesticide }\end{array}$ & Provide habitat & & & & & & & & & \\
\hline & 4 & 2 & & & & & & & & & \\
\hline \multirow[t]{2}{*}{ UK } & $\begin{array}{c}\text { Reduce } \\
\text { pesticide }\end{array}$ & $\begin{array}{l}\text { Sensitive } \\
\text { spraying }\end{array}$ & Seed dressing & Provide habitat & Beetle banks & $\begin{array}{c}\text { Hedgerow } \\
\text { management }\end{array}$ & $\begin{array}{c}\text { Grass } \\
\text { margin }\end{array}$ & ELS & HLS & Bring bees & None \\
\hline & 2 & 1 & 1 & 2 & 1 & 1 & 1 & 2 & 1 & 1 & 2 \\
\hline
\end{tabular}


Appendix F Association coefficient table (Kendall's tau b) among relevant variables

\begin{tabular}{|c|c|c|c|c|c|c|c|c|c|c|c|c|c|}
\hline & $\begin{array}{c}\text { Importance } \\
\text { of natural } \\
\text { pest } \\
\text { control }\end{array}$ & $\begin{array}{l}\text { \# of natural } \\
\text { enemies } \\
\text { mentioned }\end{array}$ & $\begin{array}{l}\text { Importan } \\
\text { ce of pest } \\
\text { damage }\end{array}$ & $\begin{array}{l}\text { \# of pests } \\
\text { mentioned }\end{array}$ & $\begin{array}{l}\text { Use } \\
\text { chemicals } \\
\text { to manage } \\
\text { pests? }\end{array}$ & $\begin{array}{c}\text { Do you use } \\
\text { chemicals } \\
\text { due to lack } \\
\text { of natural } \\
\text { enemies? }\end{array}$ & $\begin{array}{c}\text { \# to } \\
\text { promote } \\
\text { natural } \\
\text { pest } \\
\text { control } \\
\end{array}$ & $\begin{array}{l}\text { Agricultur } \\
\text { e area } \\
\text { (hectare) }\end{array}$ & $\begin{array}{l}\text { Farm } \\
\text { income }\end{array}$ & $\begin{array}{l}\text { \# of Crops } \\
\quad \text { for a } \\
\text { rotation }\end{array}$ & $\begin{array}{c}\text { In a } \\
\text { designated } \\
\text { area of } \\
\text { environment } \\
\text { al interests? }\end{array}$ & $\begin{array}{l}\text { In an agri- } \\
\text { environme } \\
\text { nt scheme? }\end{array}$ & $\begin{array}{l}\text { Years of } \\
\text { farming }\end{array}$ \\
\hline $\begin{array}{l}\text { Importance of } \\
\text { natural pest control }\end{array}$ & 1.00 & & & & & & & & & & & & \\
\hline $\begin{array}{l}\text { \# of important } \\
\text { natural enemies } \\
\text { mentioned }\end{array}$ & -0.05 & 1.00 & & & & & & & & & & & \\
\hline $\begin{array}{l}\text { Importance of pest } \\
\text { damage }\end{array}$ & 0.16 & -0.02 & 1.00 & & & & & & & & & & \\
\hline $\begin{array}{l}\text { \# of important pests } \\
\text { mentioned }\end{array}$ & $-0.26 * * *$ & 0.17 & -0.05 & 1.00 & & & & & & & & & \\
\hline $\begin{array}{l}\text { Do you use } \\
\text { chemicals to } \\
\text { manage pests? }\end{array}$ & 0.08 & 0.02 & $0.19 *$ & 0.14 & 1.00 & & & & & & & & \\
\hline $\begin{array}{l}\text { Do you use } \\
\text { chemicals due to } \\
\text { lack of natural } \\
\text { enemies? }\end{array}$ & 0.08 & -0.07 & 0.06 & 0.05 & 0.17 & 1.00 & & & & & & & \\
\hline $\begin{array}{l}\text { \# of ways } \\
\text { mentioned to } \\
\text { promote natural } \\
\text { pest control }\end{array}$ & $0.29 * * *$ & 0.11 & -0.16 & -0.05 & 0.17 & 0.17 & 1.00 & & & & & & \\
\hline $\begin{array}{l}\text { Agriculture area } \\
\text { (hectare) }\end{array}$ & -0.16 & -0.15 & 0.07 & 0.11 & $0.20 * *$ & -0.04 & 0.12 & 1.00 & & & & & \\
\hline Farm income & -0.15 & -0.11 & -0.09 & $0.24 * *$ & $0.34 * * *$ & -0.01 & $0.29 * * *$ & $0.61 * * *$ & 1.00 & & & & \\
\hline $\begin{array}{l}\text { \# of Crops for a } \\
\text { rotation }\end{array}$ & $0.22 * *$ & 0.10 & 0.06 & -0.03 & 0.11 & -0.04 & $0.16^{*}$ & -0.09 & -0.09 & 1.00 & & & \\
\hline $\begin{array}{l}\text { In a designated area } \\
\text { of environmental } \\
\text { interests? }\end{array}$ & $-0.19 *$ & 0.05 & 0.09 & 0.04 & -0.08 & $-0.29 * *$ & $-0.29 * * *$ & $0.24 * * *$ & 0.11 & $-0.17^{*}$ & 1.00 & & \\
\hline $\begin{array}{l}\text { In an agri- } \\
\text { environment } \\
\text { scheme? }\end{array}$ & 0.12 & 0.05 & 0.09 & 0.08 & 0.13 & -0.10 & 0.16 & $0.21^{* *}$ & 0.19 & -0.18 & $0.22 *$ & 1.00 & \\
\hline Years of farming & 0.05 & -0.04 & -0.01 & -0.01 & -0.02 & -0.14 & -0.06 & -0.08 & -0.06 & 0.05 & -0.02 & -0.08 & 1.00 \\
\hline
\end{tabular}

Note: '\#' denotes 'number'; importance of natural pest control/ pest damage follows the codes of: 1= 'Relatively unimportant', 2='Not as important', 3='Important',

4='Very important'; questions follow the codes of: $0=$ ' $\mathrm{No}^{\prime}, 1=$ = 'Yes'; farm income: the average annual farm income for the last two financial years, preceding the date of the survey ( $€$, following a seven point scale: $1=$ loss, $2=1-20,000,3=20,001-40,000, \ldots, 6=80,000-100,000,7=>100,000) ;$ significance levels: ${ }^{*} p<0.1, * * p<0.05$,

$* * * p<0.01$. 


\section{Appendix G}

The predicted probabilities of EU farmers' decision to promote natural pest control in relation to each predictor, while keeping other predictors constant at their average values (perceived importance of natural pest control = 'Important', number of important pests mentioned= 3, farm income $=€ 40-60,000$, whether a farm is in a designated area of environmental interests $=$ ' $N$ o').

(1) The predicted probabilities of EU farmers' decision to promote natural pest control in relation to the perceived importance of natural pest control

\begin{tabular}{|l|l|l|l|l|l|}
\hline \multirow{2}{*}{$\begin{array}{c}\text { Importance of natural } \\
\text { pest control }\end{array}$} & \multicolumn{5}{|c|}{ Predicted probabilities (95\% confidence intervals) } \\
\cline { 2 - 6 } & \# Promotion=0 & \# Promotion=1 & \# Promotion=2 & \# Promotion=3 & \# Promotion=4 \\
\hline Relatively unimportant & $0.82(0.41,0.97)$ & $0.16(0.03,0.55)$ & $0.01(0,0.11)$ & $0(0,0.01)$ & $0(0,0.01)$ \\
\hline Not as important & $0.26(0.08,0.58)$ & $0.56(0.39,0.72)$ & $0.16(0.05,0.42)$ & $0.01(0,0.08)$ & $0.01(0,0.08)$ \\
\hline Important & $0.21(0.08,0.43)$ & $0.57(0.41,0.72)$ & $0.2(0.08,0.42)$ & $0.01(0,0.09)$ & $0.01(0,0.09)$ \\
\hline Very important & $0.12(0.04,0.31)$ & $0.53(0.35,0.7)$ & $0.31(0.14,0.54)$ & $0.02(0,0.15)$ & $0.02(0,0.14)$ \\
\hline
\end{tabular}

Note: \# Promotion denotes number of ways that a respondent mentioned to promote natural pest control.

This is the same for the following tables.

(2) The predicted probabilities of EU farmers' decision to promote natural pest control in relation to the number of important pests mentioned

\begin{tabular}{|c|l|l|l|l|l|}
\hline \multirow{2}{*}{ \# of pest mentioned } & \multicolumn{5}{|c|}{ Predicted probabilities (95\% confidence intervals) } \\
\cline { 2 - 6 } & \# Promotion=0 & \# Promotion=1 & \# Promotion=2 & \# Promotion=3 & \# Promotion=4 \\
\hline 1 & $0.08(0.02,0.29)$ & $0.46(0.23,0.71)$ & $0.4(0.17,0.69)$ & $0.03(0,0.24)$ & $0.03(0,0.22)$ \\
\hline 2 & $0.11(0.03,0.32)$ & $0.52(0.32,0.71)$ & $0.33(0.14,0.59)$ & $0.02(0,0.17)$ & $0.02(0,0.16)$ \\
\hline 3 & $0.15(0.06,0.36)$ & $0.55(0.38,0.71)$ & $0.26(0.11,0.5)$ & $0.02(0,0.13)$ & $0.01(0,0.11)$ \\
\hline 4 & $0.21(0.08,0.43)$ & $0.57(0.41,0.72)$ & $0.2(0.08,0.42)$ & $0.01(0,0.09)$ & $0.01(0,0.09)$ \\
\hline 5 & $0.27(0.11,0.54)$ & $0.56(0.39,0.72)$ & $0.15(0.05,0.37)$ & $0.01(0,0.07)$ & $0.01(0,0.07)$ \\
\hline 6 & $0.35(0.13,0.67)$ & $0.53(0.33,0.72)$ & $0.11(0.03,0.33)$ & $0.01(0,0.06)$ & $0(0,0.06)$ \\
\hline 7 & $0.44(0.14,0.78)$ & $0.47(0.23,0.73)$ & $0.08(0.02,0.31)$ & $0(0,0.05)$ & $0(0,0.05)$ \\
\hline 8 & $0.53(0.15,0.87)$ & $0.41(0.14,0.75)$ & $0.06(0.01,0.3)$ & $0(0,0.04)$ & $0(0,0.04)$ \\
\hline 9 & $0.62(0.16,0.93)$ & $0.34(0.07,0.76)$ & $0.04(0,0.29)$ & $0(0,0.04)$ & $0(0,0.04)$ \\
\hline 10 & $0.7(0.17,0.96)$ & $0.27(0.04,0.78)$ & $0.03(0,0.29)$ & $0(0,0.04)$ & $0(0,0.03)$ \\
\hline
\end{tabular}

(3) The predicted probabilities of EU farmers' decision to promote natural pest control in relation to the farm income

\begin{tabular}{|c|l|l|l|l|l|}
\hline \multirow{2}{*}{$\begin{array}{c}\text { Farm income } \\
(\mathrm{K} €)\end{array}$} & \multicolumn{5}{|c|}{ Predicted probabilities $(95 \%$ confidence intervals) } \\
\cline { 2 - 6 } & \# Promotion=0 & \# Promotion=1 & \# Promotion=2 & \# Promotion=3 & \# Promotion=4 \\
\hline$<0$ & $0.64(0.29,0.88)$ & $0.32(0.11,0.64)$ & $0.04(0.01,0.18)$ & $0(0,0.02)$ & $0(0,0.02)$ \\
\hline $1-20$ & $0.48(0.21,0.76)$ & $0.44(0.23,0.68)$ & $0.07(0.02,0.24)$ & $0(0,0.04)$ & $0(0,0.03)$ \\
\hline $20-40$ & $0.33(0.14,0.6)$ & $0.54(0.36,0.71)$ & $0.12(0.04,0.31)$ & $0.01(0,0.06)$ & $0(0,0.05)$ \\
\hline $40-60$ & $0.21(0.08,0.43)$ & $0.57(0.41,0.72)$ & $0.2(0.08,0.42)$ & $0.01(0,0.09)$ & $0.01(0,0.09)$ \\
\hline $60-80$ & $0.12(0.04,0.31)$ & $0.53(0.35,0.7)$ & $0.31(0.14,0.55)$ & $0.02(0,0.15)$ & $0.02(0,0.14)$ \\
\hline $80-100$ & $0.07(0.02,0.22)$ & $0.43(0.23,0.65)$ & $0.43(0.22,0.67)$ & $0.04(0,0.25)$ & $0.03(0,0.23)$ \\
\hline$>100$ & $0.04(0.01,0.16)$ & $0.31(0.12,0.59)$ & $0.53(0.3,0.75)$ & $0.07(0.01,0.38)$ & $0.06(0.01,0.37)$ \\
\hline
\end{tabular}


(4) The predicted probabilities of EU farmers' decision to promote natural pest control in relation to 'whether a farm is located in a designated area of environmental interests'

\begin{tabular}{|c|l|l|l|l|l|}
\hline \multirow{2}{*}{$\begin{array}{c}\text { Designated } \\
\text { area }\end{array}$} & \multicolumn{5}{|c|}{ Predicted probabilities $(95 \%$ confidence intervals) } \\
\cline { 2 - 6 } & \# Promotion=0 & \# Promotion=1 & \# Promotion=2 & \# Promotion=3 & \# Promotion=4 \\
\hline No & $0.21(0.08,0.43)$ & $0.57(0.41,0.72)$ & $0.2(0.08,0.42)$ & $0.01(0,0.09)$ & $0.01(0,0.09)$ \\
\hline Yes & $0.55(0.25,0.82)$ & $0.39(0.18,0.66)$ & $0.05(0.01,0.2)$ & $0(0,0.03)$ & $0(0,0.03)$ \\
\hline
\end{tabular}

